\title{
Identification of Burkholderia mallei and Burkholderia pseudomallei adhesins for human respiratory epithelial cells
}

\author{
Rachel Balder ${ }^{1 \dagger}$, Serena Lipski ${ }^{2}$, John J Lazarus ${ }^{2}$, William Grose ${ }^{1,2}$, Ronald M Wooten², Robert J Hogan ${ }^{1}$,
} Donald E Woods ${ }^{3}$, Eric R Lafontaine ${ }^{1 *+}$

\begin{abstract}
Background: Burkholderia pseudomallei and Burkholderia mallei cause the diseases melioidosis and glanders, respectively. A well-studied aspect of pathogenesis by these closely-related bacteria is their ability to invade and multiply within eukaryotic cells. In contrast, the means by which B. pseudomallei and B. mallei adhere to cells are poorly defined. The purpose of this study was to identify adherence factors expressed by these organisms.

Results: Comparative sequence analyses identified a gene product in the published genome of B. mallei strain ATCC23344 (locus \# BMAA0649) that resembles the well-characterized Yersinia enterocolitica autotransporter adhesin YadA. The gene encoding this B. mallei protein, designated boaA, was expressed in Escherichia coli and shown to significantly increase adherence to human epithelial cell lines, specifically HEp2 (laryngeal cells) and A549 (type II pneumocytes), as well as to cultures of normal human bronchial epithelium (NHBE). Consistent with these findings, disruption of the boaA gene in B. mallei ATCC23344 reduced adherence to all three cell types by $\sim 50 \%$. The genomes of the B. pseudomallei strains $\mathrm{K} 96243$ and DD503 were also found to contain boaA and inactivation of the gene in DD503 considerably decreased binding to monolayers of HEp2 and A549 cells and to NHBE cultures. A second YadA-like gene product highly similar to BoaA (65\% identity) was identified in the published genomic sequence of B. pseudomallei strain K96243 (locus \# BPSL1705). The gene specifying this protein, termed boaB, appears to be B. pseudomallei-specific. Quantitative attachment assays demonstrated that recombinant E. coli expressing BoaB displayed greater binding to A549 pneumocytes, HEp2 cells and NHBE cultures. Moreover, a boaB mutant of $B$. pseudomallei DD503 showed decreased adherence to these respiratory cells. Additionally, a $B$. pseudomallei strain lacking expression of both boaA and boaB was impaired in its ability to thrive inside J774A.1 murine macrophages, suggesting a possible role for these proteins in survival within professional phagocytic cells.

Conclusions: The boaA and boaB genes specify adhesins that mediate adherence to epithelial cells of the human respiratory tract. The boaA gene product is shared by B. pseudomallei and B. mallei whereas BoaB appears to be a B. pseudomallei-specific adherence factor.
\end{abstract}

\section{Background}

Burkholderia pseudomallei is a Gram-negative bacterium readily recovered from the water and wet soils of endemic areas bordering the equator, particularly Southeast Asia and Northern Australia [1-9]. The organism is a motile, aerobic bacillus that can survive environmental

\footnotetext{
* Correspondence: elafon10@uga.edu

+ Contributed equally

'Department of Infectious Diseases, University of Georgia College of

Veterinary Medicine, Athens, GA 30602, USA

Full list of author information is available at the end of the article
}

extremes as well as the bactericidal activities of complement [10-12], defensins [13-15], and phagocytes [1,2,16-18]. The genome of the B. pseudomallei isolate K96243 has been published by the Wellcome Trust Sanger Institute and was shown to consist of two chromosomes of 4.1 and 3.2 Mbp [19]. Burkholderia mallei is a non-motile, host-adapted clone of $B$. pseudomallei that does not persist outside of its equine host and is endemic to certain parts of Asia, Africa, the Middle East and South America [8,9,20-25]. The genomic sequence of the B. mallei strain ATCC23344 has been published by

\section{Biomed Central}


TIGR [26] and is smaller (2 chromosomes of 3.5 and 2.3 Mbp) than that of B. pseudomallei K96243. B. mallei ATCC23344 was found to specify a large number of mobile DNA elements that have contributed to extensive deletions and rearrangements relative to the genome of B. pseudomallei K96243. Despite these differences, the genes shared by the two isolates have an average identity of $99 \%$ at the nucleotide level $[19,26]$. The genomic sequence of several B. pseudomallei and $B$. mallei isolates are also publicly available through the NCBI genomic BLAST service (http://www.ncbi.nlm.nih. gov/sutils/genom_table.cgi), which provides a wealth of resources to study these organisms.

B. pseudomallei causes the human disease melioidosis, which is notoriously difficult to diagnose. Clinical manifestations vary greatly and may present as flu-like symptoms, benign pneumonitis, acute and chronic pneumonia, or fulminating septicemia. Infection occurs via inhalation of contaminated aerosol particles or through skin abrasions, and the risk of contracting the disease is proportional to the concentration of B. pseudomallei in soil and water. In endemic areas, heavy rainfalls result in a shift from percutaneous inoculation to inhalation as the primary mode of infection, which leads to a more severe illness. Melioidosis commonly affects the lungs and is characterized by the spread of bacteria to various internal organs including the spleen and liver. Many patients become bacteremic and the mortality rate is high (19-51\%) despite aggressive antimicrobial therapy [1-9]. B. pseudomallei is refractory to most antibiotics and resistance mechanisms include efflux pumps and $\beta$-lactamases [27-36]. The recommended treatment entails the use of ceftazidime, carbapenems, TMP-SMZ, chloramphenicol and/or Augmentin for several weeks. Response to treatment is slow and eradication of $B$. pseudomallei is difficult to achieve, resulting in recrudescence [1,37-39].

B. mallei causes the zoonosis glanders, which primarily affects solipeds $[8,9,20-25]$. In humans, infection occurs by contact with infected animals via the cutaneous or respiratory route. The clinical manifestations of the disease include febrile pneumonia associated with necrosis of the tracheobronchial tree or pustular skin lesions and the development of abscesses. Most patients become bacteremic and $B$. mallei disseminates to the liver and spleen where it rapidly causes necrosis. Even with antibiotic treatment, the mortality rate for human glanders is $50 \%$ and the basis for this high mortality rate is not understood, though $B$. mallei has been shown to be resistant to complement-mediated killing [40], macrophages [41] and antimicrobials [32,42].

One key aspect of pathogenesis by $B$. mallei and B. pseudomallei is their ability to invade and multiply within a variety of eukaryotic cells, where bacteria are shielded from the host humoral immune response and antibiotics. Once internalized, B. mallei and B. pseudomallei escape from endocytic vacuoles and enter the cytoplasm of infected cells where they multiply. The organisms subsequently spread to neighboring cells through a process involving the formation of actin tails and membrane protrusions that push bacteria from one cell to another. This intracellular lifestyle is crucial to virulence and has been a focus of research efforts aimed at understanding pathogenesis by B. mallei and B. pseudomallei [2,9,16-18,22,41,43-49]. Several gene products, such as BimA, type 3 secretion system effectors, and type 6 secretion proteins, have been shown to play key roles in this process. By contrast, the mechanisms used by these organisms to adhere to eukaryotic cells are poorly defined. Adherence is an essential step of pathogenesis by most infectious agents because it is necessary for colonizing a new host [50-52]. Moreover, B. pseudomallei and B. mallei are facultative intracellular pathogens that gain access to the interior of target cells. Though not always a prerequisite for this process, bacterial adherence is a widespread strategy that precedes and promotes invasion [50-52]. Thus far, only the B. pseudomallei flagellum [53] and type 4 pilus [54] have been implicated in adherence and their exact roles remain to be elucidated. The present study reports the identification of B. pseudomallei and B. mallei gene products that mediate adherence to epithelial cells derived from the human respiratory tract, thus relevant to the aerosol route of infection by these organisms.

\section{Results}

Identification of a gene shared by $B$. mallei and $B$. pseudomallei that encodes a potential autotransporter adhesin

Analysis of the annotated genomic sequence of $B$. mallei ATCC23344 identified the ORF locus tag number BMAA0649 as resembling members of the oligomeric coiled-coil adhesin (Oca) family of autotransporter proteins [55]. Yersinia enterocolitica YadA [55-57] is the prototypical member of this group of adherence factors, which also includes Haemophilus influenzae Hia [58-60] and Moraxella catarrhalis Hag $[61,62]$. These Oca proteins share structural features including a C-terminal outer membrane (OM) anchor domain composed of 4 $\beta$-strands (also referred to as the transporter module), a surface-exposed passenger domain often containing repeated amino acid (aa) motifs, and a helical region of $\sim 40$ residues that connects the OM anchor to the surface-exposed passenger domain [55,63-65]. As illustrated in Fig 1A, BMAA0649 is predicted to possess these features. Further sequence analysis of the $B$. malle $i$ ATCC23344 gene product revealed that residues 208362 (and 1010-1149) contain repeats with the consensus xxxAVAIGxx[N/A]xAx (open circles in Fig 1A), which 


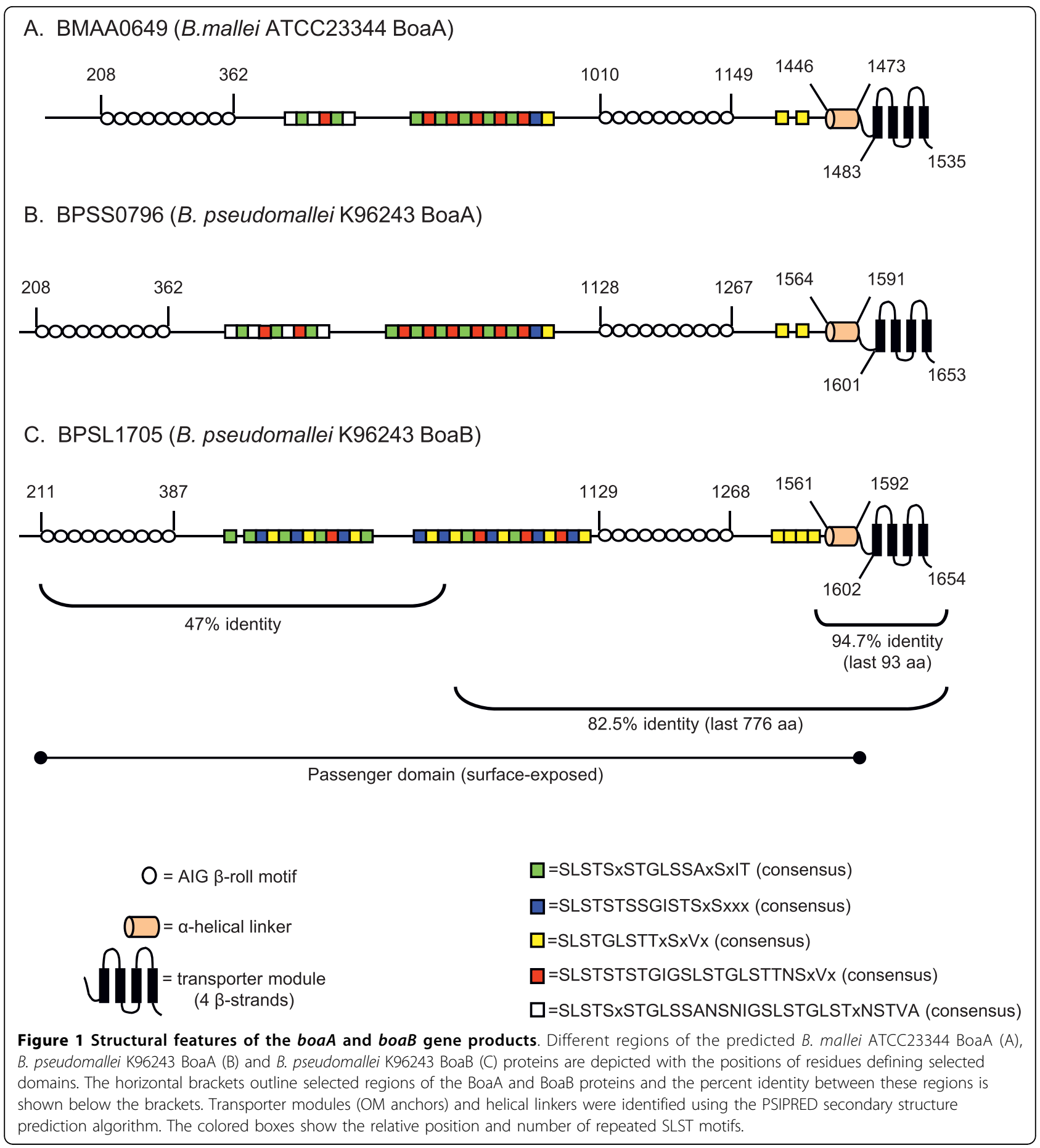

resemble motifs found in the $\mathrm{N}$-terminus of $Y$. enterocolitica YadA (xxxSVAIGxxSxAx) [56,57] and M. catarrhalis Hag (GxxSIAIGxx[A/S]xAx) [61]. In YadA, these AIG patterns have been shown to form a structure termed a $\beta$-roll and to specify adhesive properties. The passenger domain of BMAA0649 was also found to contain several serine-rich repeats beginning with residues SLST (colored squares in Fig 1A). Additionally, searches using the Pfam database indicated that aa 1456-1535 of BMAA0649 encode a YadA-like C-terminal domain (PF03895; expect value $3.8 \mathrm{e}^{-11}$ ), which is present in most Oca molecules and is described as important for oligomerization. Taken together, these observations suggest structural and functional similarities between BMAA0649 and members of the Oca family of autotransporters. Hence, we designated this ORF of B. mallei 
Table 1 Characteristics $^{a}$ of boaA and boaB genes and their encoded products

\begin{tabular}{|c|c|c|c|c|c|c|c|c|}
\hline Strain & Gene & Chromosome & Locus tag & $\begin{array}{c}\text { GenBank accession } \\
\#\end{array}$ & $\begin{array}{l}\text { ORF } \\
\text { (nt) }\end{array}$ & $\begin{array}{l}\text { Predicted } \\
\text { protein } \\
\text { (aa) }\end{array}$ & $\begin{array}{l}\text { MW } \\
(\mathrm{Da})\end{array}$ & $\begin{array}{c}\text { Potential signal } \\
\text { sequence } \\
\text { cleavage site }^{\mathrm{b}}\end{array}$ \\
\hline \multicolumn{9}{|l|}{ B.mallei } \\
\hline ATCC23344 & boaA & 2 & BMAA0649 & YP_105401.1 & 4608 & 1535 & 140,689 & $W A^{18} \cdot G V$ \\
\hline NCTC10247 & boaA & 2 & BMA10247_A1776 & YP_001078959.1 & 5301 & 1766 & 162,744 & $W A^{77} \mathbf{v G V}$ \\
\hline \multicolumn{9}{|l|}{ B. pseudomallei } \\
\hline K96243 & boaA & 2 & BPSS0796 & YP_110805.1 & 4962 & 1653 & 151,565 & $W A^{18} \mathbf{G V}$ \\
\hline DD503 & boaA & ND & - & EF423807 & 4680 & 1559 & 143,209 & $W A^{18} \mathbf{A L}$ \\
\hline $1710 b$ & boaA & 2 & BURPS1710b_A2381 & YP_337531.1 & 4881 & 1626 & 149,383 & $W A^{10} \mathbf{v A L}$ \\
\hline K96243 & boab & 1 & BPSL1705 & YP_108306.1 & 4821 & 1606 & 148,811 & $V A^{23} \mathbf{G T}$ \\
\hline DD503 & boab & ND & - & EF423808 & 4965 & 1654 & 154,117 & $V A^{71} \mathbf{v G T}$ \\
\hline $1710 \mathrm{~b}$ & boab & 1 & BURPS1710b_2168 & YP_333563.1 & 4965 & 1654 & 154,059 & $\mathrm{VA}^{71} \mathbf{v} \mathrm{GT}$ \\
\hline
\end{tabular}

${ }^{a}$ Sequence analyses were performed using Vector NTI (Invitrogen) and online tools available through the ExPASy Proteomics Server.

${ }^{\mathrm{b}}$ The putative signal sequence cleavage site was determined using the SignalP 3.0 server.

ND $=$ not determined.

ATCC23344 boaA ( $\underline{B}$ urkholderia $\underline{O}$ ca-like adhesin $\underline{A}$ ). Table 1 lists characteristics of the boaA gene and its encoded product.

The published genome of B. pseudomallei K96243 was also found to specify a boaA gene product (BPSS0796, Fig $1 \mathrm{~B}$ ) that is $92.7 \%$ identical to that of $B$. mallei ATCC23344. Oligonucleotide primers were designed to amplify the entire boaA gene from the B. pseudomallei strain used in our laboratory, DD503, and sequence analysis of this amplicon predicted a gene product that is $94.4 \%$ and $90.6 \%$ identical to BoaA of B. mallei ATCC23344 and B. pseudomallei K96243, respectively. Database searches with the NCBI genomic BLAST service also identified boaA in several $B$. pseudomalle $i$ and B. mallei isolates. All nine B. mallei and 23 B. pseudomallei strains for which sequences are available through this service were found to have the gene. Characteristics of some of these ORFs are listed in Tables 1 and 2 . Overall, the BoaA proteins are $82-94 \%$ identical and differ primarily in the number and/or arrangement of SLST repeats in their predicted passenger domains (data not shown). Based on these results, we conclude that BoaA is a well-conserved gene product shared by $B$. mallei and B. pseudomallei.

\section{Identification of a $B$. pseudomallei-specific gene encoding} a putative autotransporter adhesin that resembles BoaA

Further analysis of the annotated genomic sequence of B. pseudomallei K96243 identified the ORF locus tag number BPSL1705 as specifying a second Oca-like protein that is $\sim 60 \%$ identical to BoaA. The last 776 aa of BPSL1705 and BoaA are $82.5 \%$ identical (Fig 1) and the very last 93 residues, which encompass the predicted $\mathrm{C}$-terminal $\mathrm{OM}$-anchoring domain and $\alpha$-helical region

Table 2 Percent identity shared by boaA and boaB gene products

\begin{tabular}{|c|c|c|c|c|c|c|c|c|}
\hline & $\begin{array}{c}\text { BoaA (Bm } \\
\text { ATCC23344) }\end{array}$ & $\begin{array}{c}\text { BoaA (Bm } \\
\text { NCTC10247) }\end{array}$ & $\begin{array}{c}\text { BoaA (Bp } \\
\text { K96243) }\end{array}$ & $\begin{array}{l}\text { BoaA (Bp } \\
\text { DD503) }\end{array}$ & $\begin{array}{c}\text { BoaA (Bp } \\
1710 b)\end{array}$ & $\begin{array}{c}\text { BoaB (Bp } \\
\text { K96243) }\end{array}$ & $\begin{array}{l}\text { BoaB (Bp } \\
\text { DD503) }\end{array}$ & $\begin{array}{c}\text { BoaB (Bp } \\
1710 \mathrm{~b})\end{array}$ \\
\hline $\begin{array}{c}\text { BoaA (Bm } \\
\text { ATCC23344) }\end{array}$ & 100 & & & & & & & \\
\hline $\begin{array}{l}\text { BoaA (Bm } \\
\text { NCTC10247) }\end{array}$ & 86.9 & 100 & & & & & & \\
\hline $\begin{array}{l}\text { BoaA (Bp } \\
\text { K96243) }\end{array}$ & 92.7 & 89.2 & 100 & & & & & \\
\hline $\begin{array}{l}\text { BoaA (Bp } \\
\text { DD503) }\end{array}$ & 94.4 & 82.2 & 90.6 & 100 & & & & \\
\hline BoaA (Bp 1710b) & 90.4 & 83.1 & 92.4 & 93.6 & 100 & & & \\
\hline $\begin{array}{l}\text { BoaB (Bp } \\
\text { K96243) }\end{array}$ & 64 & 60 & 65 & 63.9 & 63.9 & 100 & & \\
\hline $\begin{array}{c}\text { BoaB (Bp } \\
\text { DD503) }\end{array}$ & 62 & 60.8 & 62.9 & 61.9 & 62.2 & 96.7 & 100 & \\
\hline BoaB (Bp 1710b) & 62.2 & 60.9 & 63.2 & 62.1 & 62.4 & 97 & 99.7 & 100 \\
\hline
\end{tabular}

$B m=B$. mallei.

$B p=B$. pseudomallei. 


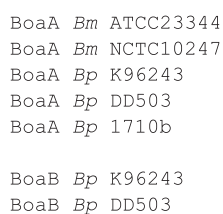

Figure 2 Sequence comparison of $\mathbf{b o a} \boldsymbol{A}$ and $\mathbf{b o a} \boldsymbol{B}$ gene products. The last 93 residues of selected boaA and boaB gene products are shown with the positions of the aa defining these regions in parentheses. Perfectly conserved aa are shown in black text over white background. Residues unique to BoaA proteins are shown in blue text over a yellow background. Residues unique to BoaB proteins are shown in white text over a blue background. $B m=B$. mallei, $B p=B$. pseudomallei.

of the molecules, were found to be particularly well-conserved (94.7\% identity, Fig 1 and 2). The BPSL1705 ORF is predicted to encode a protein of $148-\mathrm{kDa}$ which, as depicted in Fig $1 \mathrm{C}$, possesses many of the structural features observed in BoaA including two sets of $\beta$-roll AIG motifs with the consensus $x x G(S / A)(V / I) A I G x x(N / A)$ $x A x$ and several SLST repeats. This high level of sequence and structural similarity between BPSL1705 and BoaA prompted us to designate this B. pseudomallei K96243 gene product BoaB.

The boaB gene was sequenced from $B$. pseudomallei DD503 and was predicted to encode a protein that is 96.7\% identical to BoaB of B. pseudomallei K96243. Database searches using NCBI genomic BLAST revealed that the genomes of at least 10 more B. pseudomalle strains contain the gene. Overall, the BoaB proteins are highly-conserved (90-99\% identity) and characteristics of the ORF from selected strains are shown in Tables 1 and 2 and Fig 2 for comparison purposes. Importantly, database searches also revealed that none of the $B$. mallei isolates available through the NCBI genomic BLAST service have a boaB gene. Taken together, these results indicate that BoaB is a highly-conserved B. pseudomallei-specific molecule.

\section{Expression of the Burkholderia BoaA and BoaB proteins in E. coli}

Because of their sequence and structural similarities to known bacterial adhesins, we hypothesized that BoaA and BoaB mediate adherence to human epithelial cells. To test this hypothesis, the $B$. mallei ATCC23344 boaA and $B$. pseudomallei DD503 boaB genes were cloned into the E. coli strain EPI300. This organism does not normally adhere well to human epithelial cells $[61,62,66]$ and therefore provides an appropriate heterologous genetic background for examining the adhesive properties of BoaA and BoaB. To verify gene expression, RNA was prepared from $E$. coli harboring the plasmids pCC1.3 (control), pSLboaA (specifies B. mallei ATCC23344 boaA) and pSLboaB (specifies B. pseudomallei DD503 boa $B$ ), and analyzed by quantitative Reverse-Transcriptase PCR (qRT-PCR). Fig 3A demonstrates that the boaA and boa $B$ genes are expressed by recombinant bacteria and that the primers used in these experiments are specific for their corresponding genes. Sarkosyl-insoluble OM proteins were also extracted from $E$. coli cells and analyzed by western blot to ensure production of the Burkholderia proteins. Fig 3B shows that $\alpha$-BoaA antibodies (Abs) react with a band of $130-\mathrm{kDa}$ in the OM of $E$. coli expressing boaA (lane 3) whereas Abs against BoaB bind to a $140-\mathrm{kDa}$ antigen in E. coli expressing boaB (lane 5). These molecular weights (MWs) are consistent with the predicted masses of the gene products (Table 1).

In addition to showing that BoaA and BoaB are associated with the $\mathrm{OM}$ by protein separation and western blot, we used immunofluorescent labeling of nonpermeabilized $E$. coli cells to demonstrate their display on the bacterial surface. As depicted in Fig 3C, E. coli harboring pSLboaA and pSLboaB are labeled by the $\alpha$-BoaA and $\alpha$-BoaB Abs, respectively, while recombinant bacteria carrying the control plasmid pCC1.3 are not. Staining of nucleic acids with the fluorescent dye DAPI verified that comparable numbers of bacterial cells were examined (Fig 3C). Quantitative attachment assays revealed that $E$. coli expressing BoaB attach to HEp2 (laryngeal) and A549 (type II pneumocytes) epithelial cell lines at levels 18- and 68-fold greater than bacteria carrying pCC1.3, respectively (Fig 3D). In addition, BoaB expression was found to increase adherence to differentiated primary cultures of normal human bronchial epithelium (NHBE). Under the growth conditions used, NHBE cultures form a pseudostratified epithelium with tight junctions containing both ciliated and non-ciliated cells. This epithelium exhibits transepithelial resistance, mucus secretion, mucociliary activity, and an apical surface not submerged in tissue culture medium, thus representing an environment that is similar to the airway lumen in vivo [67-69]. Expression of the B. mallei ATCC23344 BoaA protein on the surface of $E$. coli also substantially increased adherence to monolayers of A549 and HEp2 cells and to NHBE cultures. Taken together, these data demonstrate that BoaA and $\mathrm{BoaB}$ are $\mathrm{OM}$ proteins mediating adherence to epithelial cells of the human respiratory tract. 


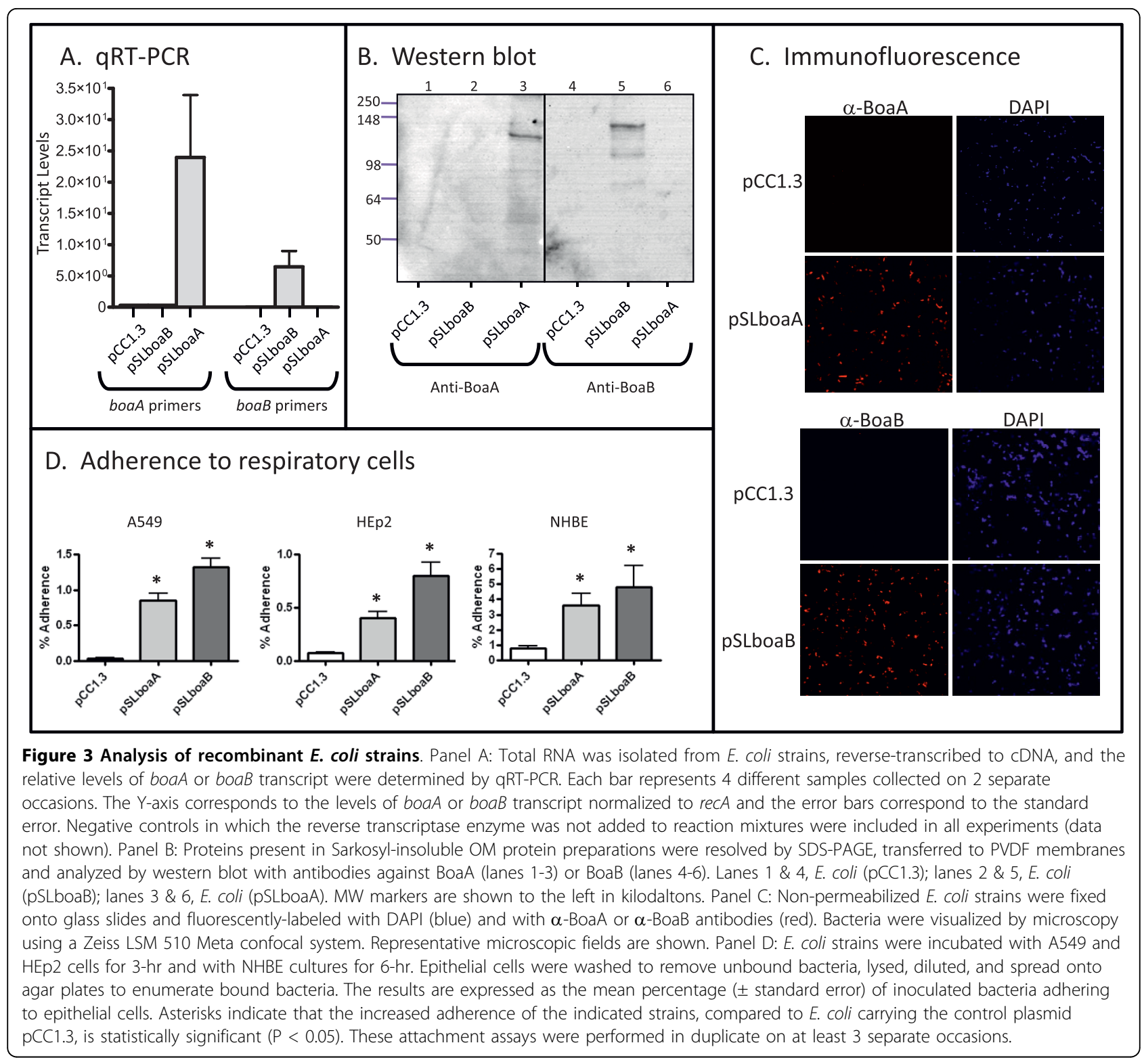

B. pseudomallei and B. mallei are facultative intracellular organisms that can invade, survive and replicate in a variety of eukaryotic cells. Moreover, autotransporter adhesins often specify additional biological functions such as invasion [70], biofilm formation [71], survival within host cells [72] and intracellular motility [16]. For these reasons, we measured the ability of $E$. coli expressing BoaA and BoaB to invade epithelial cells as well as their ability to survive within murine macrophages. We also measured the ability of these recombinant strains to form biofilms on the plastic support of tissue culture plates using a crystal violet-based assay. The results of these experiments indicated that neither BoaA nor BoaB substantially increase invasion of epithelial cells, phagocytosis of recombinant bacteria by J774A.1 murine macrophages, survival inside these immune cells, or biofilm formation (data not shown).

\section{Construction and characterization of Burkholderia mutant strains}

To study the functional properties of the boa gene products in the native Burkholderia background, we constructed isogenic boaA mutants of B. pseudomallei DD503 and B. mallei ATCC23344 as well as an isogenic boaB mutant of $B$. pseudomallei DD503. A double mutant strain was also engineered in which inactivated versions of both boaA and boaB were introduced in the genome of B. pseudomallei DD503. Whole cell lysates and sarkosyl-insoluble OM proteins were prepared from these strains and analyzed by western blot to verify lack 
of BoaA and BoaB expression in the mutants. The $\alpha$-BoaA and $\alpha$-BoaB Abs, however, did not react with Burkholderia protein preparations (data not shown). In order to determine whether the genes are expressed, total RNA was isolated from B. pseudomallei DD503 and $B$. mallei ATCC23344 and the relative transcript levels of boaA and boaB were assessed by qRT-PCR. Fig 4 shows that boaA and boaB are expressed by B. pseudomallei while $B$. mallei only expresses boaA, which is in agreement with database searches revealing that $B$. mallei isolates do not contain a boaB gene. The qRTPCR data also demonstrate that the genes are expressed at very low levels compared to Burkholderia recA, which was used to normalize boaA and boaB transcript levels. These results are consistent with our inability to visualize the proteins by western blot. Other methods such as immunoprecipitation and immunofluorescence labeling also proved unsuccessful at detecting production of BoaA and BoaB by Burkholderia strains.

Quantitative attachment assays with recombinant bacteria indicated that BoaA or BoaB expression significantly increases the adherence of $E$. coli to monolayers of A549 and HEp2 cells and to NHBE cultures (Fig 3D). We therefore compared the ability of

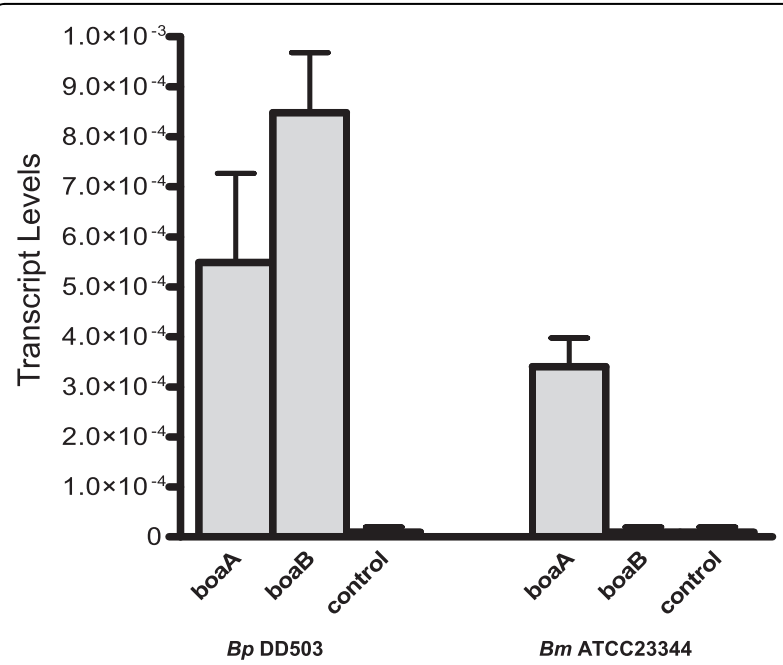

Figure 4 Quantitative reverse-transcriptase PCR analysis of $B$. mallei and $B$. pseudomallei strains. Total RNA was isolated from $B$. pseudomallei (Bp) DD503 and B. mallei (Bm) ATCC23344, reversetranscribed to $C D N A$, and the relative levels of boaA or boaB transcript was determined by qRT-PCR. Each bar represents 4 different samples collected on 2 separate occasions. The Y-axis corresponds to levels of boaA or boaB transcript normalized to rec $A$ and the error bars correspond to the standard error. A primer set for Borrelia burgdorferi recA was used as a control to further demonstrate primer specificity (see bars labeled as control). Of note, negative controls in which the reverse transcriptase enzyme was not added to reaction mixtures were included in all experiments and the results were equivalent to the Borrelia burgdorferi controls (data not shown)
Burkholderia parent and boa mutant strains to attach to these respiratory cells. As shown in Fig $5 \mathrm{~A}$ and $5 \mathrm{D}$, inactivation of the boaA gene in B. mallei ATCC23344 and $B$. pseudomallei DD503 decreases adherence to A549 cells by 60 and 53\%, respectively. The boaA mutation also caused a $50 \%$ reduction in the binding of B. pseudomallei to HEp2 monolayers (Fig 5B), and reduced adherence of $B$. mallei to these laryngeal cells by $67 \%$ (Fig $5 \mathrm{E}$ ). Moreover, both boaA mutant strains displayed significant impairment in their abilities to attach to NHBE cultures (Fig $5 \mathrm{C}$ and $5 \mathrm{~F}$ ). The boaB mutation in B. pseudomallei DD503 decreased attachment to A549 and HEp2 cells by $~ 50 \%$ (Fig $5 \mathrm{~A}$ and $5 \mathrm{~B}$, respectively) and caused a $62 \%$ reduction in adherence to NHBE cultures (Fig 5C). As expected, the double mutant strain DD503.boaA.boaB exhibited significantly lower attachment to epithelial cells compared to the parent strain DD503 (Fig 5A, B, and 5C). The adherence levels of the double mutant, however, did not differ significantly from that of the single mutants in any of the cell types tested. One possible explanation for this apparent lack of synergistic effect is that other adhesins expressed by the double mutant strain DD503.boaA.boaB provide a high background level of adherence. Taken together, these results demonstrate that the boaA and boaB gene products contribute to the adherence of $B$. mallei and B. pseudomallei to epithelial cells of the human respiratory tract.

As previously stated, autotransporter adhesins often specify additional biological functions including survival within host cells [72]. In addition, B. pseudomallei and $B$. mallei are facultative intracellular pathogens that are particularly proficient at replicating inside professional phagocytic cells. For these reasons, we measured the ability of our panel of Burholderia mutant and parent strains to replicate within J774A.1 murine macrophages. In B. pseudomallei DD503, inactivation of the boa genes had no effect on phagocytosis of the organism (Fig 6A). Once inside macrophages, the boaA (DD503.boaA) and boaB (DD503.boaB) single mutants replicated at rates equivalent to that of the progenitor strain DD503 (Fig 6B). However, when both boaA and boaB genes were disrupted (DD503.boaA.boaB), intracellular growth was diminished by $60 \%$ (Fig 6B). To verify that this reduced intracellular fitness was not due to a global growth defect, we measured the growth of strains DD503 and DD503.boaA.boaB in broth as well as in tissue culture medium. We found that both strains grew at equivalent rates under both conditions (data not shown). Interestingly, the double mutant did not exhibit a growth defect in epithelial cells (data not shown). These results suggest a role for the BoaA and BoaB proteins in B. pseudomallei's ability to grow inside professional phagocytes. No 


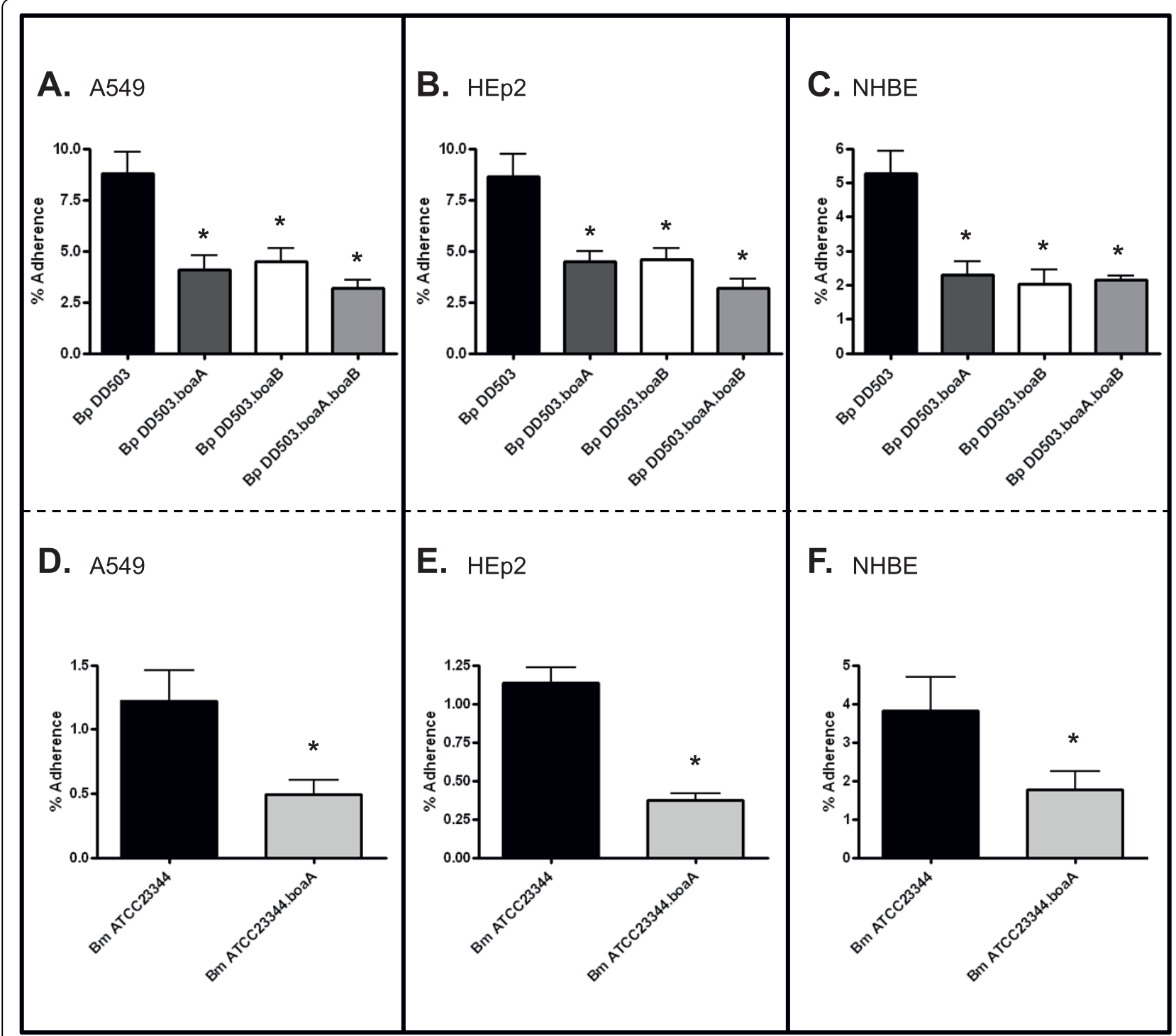

Figure 5 Adherence of $B$. mallei and $B$. pseudomallei strains to human respiratory epithelial cells. The effects of boa $A$ and boa $B$ mutations on the adherence of B. pseudomallei (Bp) DD503 and B. mallei (Bm) ATCC23344 to monolayers of A549 (panels A and D) and HEp2 (panels B and E) cells and cultures of NHBE (panels C and F) was measured in duplicate on at least 3 separate occasions. The results are expressed as the mean percentage ( \pm standard error) of inoculated bacteria adhering to epithelial cells. Asterisks indicate that the difference between the adherence of the mutant and that of the parental strain is statistically significant $(P<0.05)$.

defect in uptake or intracellular growth was measured for the B. mallei ATCC23344 boaA mutant strain (data not shown). It should also be noted that none of the boa mutants showed decreased biofilm formation on the plastic support of tissue culture plates nor defects in resistance to the bactericidal activity of normal human serum (data not shown), both biological functions that are also commonly associated with Oca autotransporter adhesins [56,63,73-75].

\section{Discussion}

Autotransporters are involved in various biological traits of Gram-negative bacteria including invasion [70], serum resistance [56,73], phospholipolysis [76,77], cytotoxicity [78], adherence [61,79], biofilm formation $[71,80]$, survival within eukaryotic cells $[72]$ and intracellular motility [16]. These proteins share an N-terminal extracellular passenger domain that specifies the biological activity of the autotransporter and a C-terminus containing several $\beta$-strands, which tether the molecule to the OM. Based on the structure of this membraneanchoring domain, autotransporters can be classified as conventional (contain $12 \beta$-strands) or trimeric (contain $4 \beta$-strands) [65]. One of the best characterized trimeric autotransporters is the $Y$. enterocolitica adhesin YadA. This protein, along with structurally-related adherence 


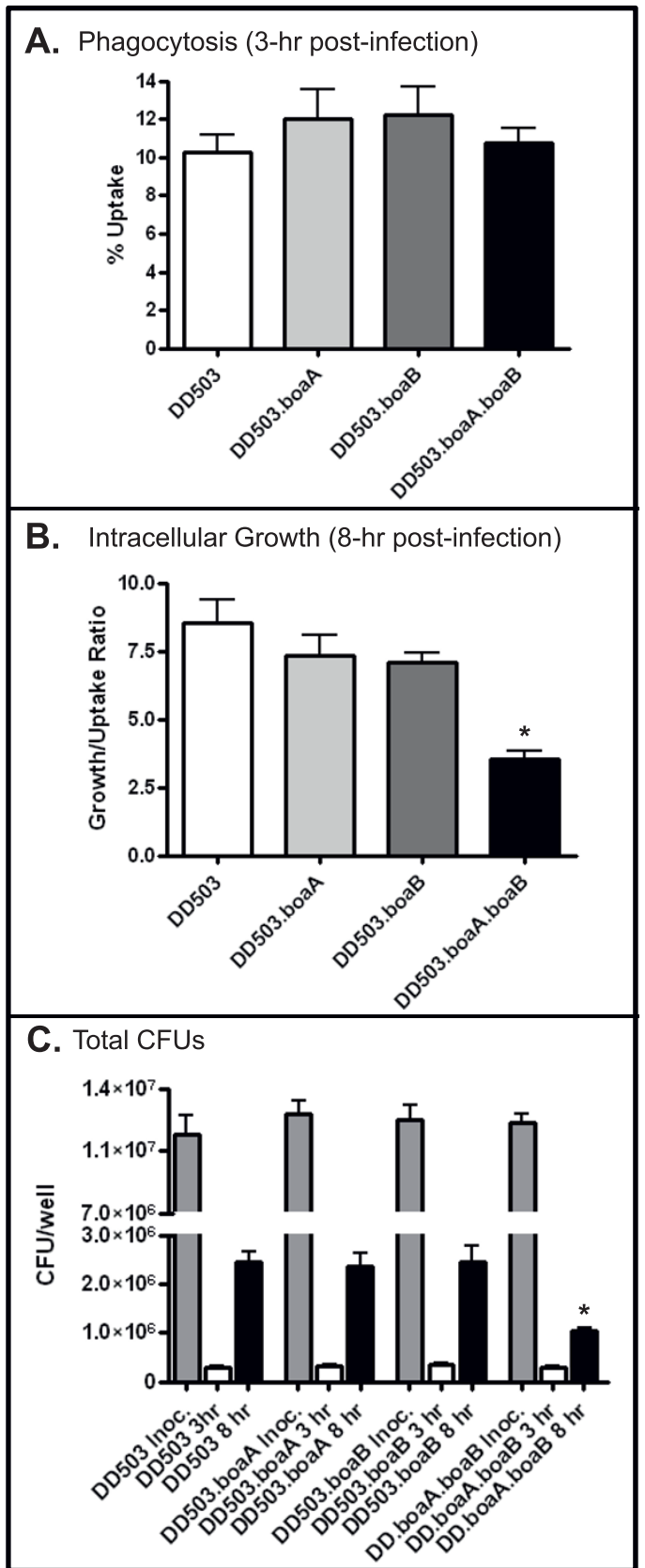

Figure 6 Uptake and growth of B. pseudomallei strains in J774A.1 murine macrophages. J774A.1 cells (duplicate wells in each of two 24well tissue culture plates) were infected with B. pseudomallei strains at an $\mathrm{MOI}$ of 10 and incubated for 1-hr to allow phagocytosis of the organisms. Following incubation, the monolayers were incubated for 2-hr in medium containing gentamicin to kill extracellular bacteria. After gentamicin treatment (i.e. 3-hr post infection), the wells of one plate were washed, lysed, serially diluted, and spread onto agar plates to determine the number of bacteria phagocytosed by macrophages. The results of this first part of the experiments (i.e. bacterial uptake) are shown in panel A and are expressed as the percentage of bacteria ( \pm standard error) used to infect macrophages that were phagocytosed. The wells of the other tissue culture plate inoculated with B. pseudomallei strains were washed once, fresh medium without antibiotics was added to wells, and the plate was incubated for an additional 5-hr. Following this incubation (i.e. 8-hr post-infection), the wells were processed as described above in order to enumerate bacterial numbers. The results of this second part of the experiments (i.e. intracellular growth of phagocytosed bacteria) are shown in panel B and are expressed as a growth/uptake ratio ( \pm standard error) obtained by dividing the number of bacteria/well at 8-hr post infection by the number of bacteria/well at the 3-hr post infection time point. These experiments were repeated on at least 3 separate occasions. The asterisk indicates that the difference between the intracellular growth of the double mutant strain DD503.boaA. boaB and that of its parent isolate DD503 is statistically significant $(P<0.05)$. Panel $\mathrm{C}$ shows the total number of bacteria in the inoculum (grey bars), the number of phagocytosed bacteria (open bars, 3-hr post infection) and the total number of bacteria/well at the end point of the experiment (black bars, 8-hr post infection). 
proteins such as $M$. catarrhalis Hag and $H$. influenzae Hia, are often referred to as oligomeric coiled-coil adhesins (Oca) [55].

Tiyawisutsri and colleagues previously reported that the published genomic sequences of $B$. pseudomalle $i$ K96243 and B. mallei ATCC23344 contain several ORFs encoding putative trimeric autotransporters [81]. Of these, only BimA (i.e. B. pseudomallei and B. mallei locus tag numbers BPSS1492 and BMAA0749, respectively) has been functionally characterized and shown to be required for actin-based motility of the organisms inside eukaryotic cells $[16,17]$. In the present study, we identified the boaA ORF based on similarities to the Oca proteins $Y$. enterocolitica YadA and $M$. catarrhalis Hag. Specifically, we searched the genome of $B$. malle $i$ ATCC23344 for gene products specifying N-terminal AIG $\beta$-roll motifs, a transporter module containing $4 \beta$-strands, and a YadA-like C-terminal domain (PF03895). We demonstrated that when expressed by $E$. coli, boaA increases adherence to the human epithelial cell lines HEp2 (laryngeal cells) and A549 (type II pneumocytes) grown as monolayers in submerged cultures. Though these cell types are relevant to the aerosol route of infection by B. mallei and B. pseudomallei, they lack important features of the airway mucosa such as cilia and mucociliary activity. The ciliated cells of the respiratory tract and other mucosal membranes keep secretions moving and contribute to preventing colonization by pathogens. For these reasons, we also measured the adherence of E. coli expressing BoaA to cultures of normal human bronchial epithelium (NHBE) grown in an air-liquid interface system. These cultures mimic the structure and function of the airway mucosa more accurately as they are fully differentiated, form a pseudostratified epithelium with tight junctions, contain ciliated and mucus-producing goblet cells, and exhibit mucociliary activity [67-69]. Quantitative attachment assays utilizing this culture system revealed that BoaA expression increases adherence to NHBE cultures (Fig 3D).

In addition to showing that BoaA specifies adhesive properties when expressed in the heterologous genetic background of $E$. coli, we determined that disruption of the boaA gene in the genome of B. mallei ATCC23344 reduces adherence of the organism to monolayers of HEp2 and A549 cells and to NHBE cultures, therefore substantiating the function of BoaA as an adhesin. Database searches using the NCBI genomic BLAST service identified boaA in several B. pseudomallei and B. mallei isolates and we demonstrated that inactivation of boaA in the B. pseudomallei strain DD503 also decreases attachment to HEp2 laryngeal cells, A549 pneumocytes, and NHBE cultures. Together, our data indicate that BoaA is an adhesin common to B. mallei and B. pseudomallei and mediates adherence to host cells relevant to pathogenesis by the organisms. These findings are consistent with the recent inclusion of BoaA (i.e. B. mallei ATCC23344 and B. pseudomallei K96243 locus tag numbers BMAA0649 and BPSS0796, respectively) in the virulome of $B$. mallei and $B$. pseudomallei, which consists of a set of 650 putative virulence genes that are shared by B. pseudomallei and B. mallei but are not present in five closely-related non-pathogenic Burkholderia species [82].

Comparative genomic analyses revealed that several $B$. pseudomallei isolates possess a second Oca-like gene product highly similar to BoaA, which we termed BoaB. The C-terminus of BoaB is strikingly similar to that of BoaA (Fig 2) and the predicted passenger domains of the molecules contain numerous matching serine-rich SLST motifs (Fig 1). The proteins are also functionally related as they mediate adherence to the same types of host cells (Fig 3D and 5). Therefore, it is tempting to speculate that boaA and boaB are the result of gene duplication. This hypothesis would be consistent with the genomic organization of the genes. In B. pseudomallei strains K96243, 1710b, 1655, 576 and MSHR346, the boa $B$ gene is located on chromosome 1 while boaA is on chromosome 2 . Moreover, the boaB gene in all these isolates is preceded by two ORFs specifying an invertase and a transposase. These genes may be the remnants of mobile genetic elements possibly involved in gene duplication. Database searches also revealed that $B$. mallei isolates do not possess a boaB gene, which was likely lost during evolution of the organism into a hostadapted pathogen. Interestingly, the closely-related bacterium Burkholderia thailandensis has been reported by others to bind poorly to epithelial cells [83]. This organism exhibits high genomic similarities to $B$. pseudomal$l e i$ and $B$. mallei and, like B. pseudomallei, is a natural inhabitant of the tropical soil environment. However, $B$. thailandensis is not considered pathogenic to humans or higher animals [84-87]. This difference in virulence can be attributed to the fact that $B$. thailandensis does not produce a capsule [88] and lacks the 650 genes comprising the aforementioned virulome of $B$. malle $i$ and B. pseudomallei. Analysis of the published genome of the B. thailandensis strain E264 [89] indicated that it contains neither the boaA nor the boaB gene.

B. pseudomallei DD503 and B. mallei ATCC23344 do not produce detectable amounts of the BoaA and BoaB proteins under the conditions tested. These results are consistent with qRT-PCR experiments demonstrating that the organisms express very low levels of the boa genes relative to the Burkholderia recA control (Fig 4). Similar observations were made by Druar and colleagues while studying expression of the Burkholderia Type 3 Secretion System-3 (T3SS-3) proteins BipB and BipD [90]. These proteins were not detected in lysates of 
B. pseudomallei or B. mallei grown under different conditions, even though the antibodies used in their western blot experiments recognized recombinant forms of BipB and BipD. The authors concluded that these two T3SS3 molecules must be expressed in detectable amounts only under very specific in vitro conditions [90]. Using a $g f p$ reporter strain, Burtnick et al recently showed that the B. mallei Type 6 Secretion System-1 (T6SS-1) gene $t s s E$ is not expressed at detectable levels when bacteria are grown in LSLB or tissue culture medium, but is expressed upon phagocytosis of the organisms by murine macrophages [49]. The protein preparations tested in our studies were obtained from bacteria cultured on LSLB agar plates at $37^{\circ} \mathrm{C}$, conditions which may not be optimal for expression of the BoaA and BoaB proteins. Additionally, Chantratita and colleagues reported that growth of $B$. pseudomallei under various conditions triggers a complex adaptive process altering the expression of surface molecules [91]. This process, termed phenotypic plasticity, was correlated with changes in the morphology of B. pseudomallei colonies grown on agar plates and appears to modulate the environmental fitness, as well as virulence, of the organism. Given their surface location and likely role in virulence (i.e. adherence to host cells), it is possible that BoaA and BoaB are subject to phenotypic plasticity and are expressed in detectable amounts only under very specific in vitro conditions. In concordance, the reduced adherence phenotype of the boaA and boaB mutant strains suggests increased level of expression of the genes when Burkholderia is incubated with epithelial cells. However, efforts to detect protein expression under these conditions (i.e. immunofluorescence, immunoprecipitation) have been unsuccessful. Of further note, studies have shown that sera from horses infected with B. mallei and sera from melioidosis patients contain antibodies reacting with BoaA (i.e. B. mallei ATCC23344 locus tag number BMAA0649) [81] and with BoaB (i.e. B. pseudomallei K96243 locus tag number BPLS1705) [92], respectively, which indicates expression of the autotransporters in vivo. Determining the conditions and mechanisms that modulate expression of the Boa adhesins, and their influence on the binding of B. pseudomallei and B. mallei to host surfaces, represent key areas for future study.

Disruption of boaA and boaB in the B. pseudomallei double mutant strain DD503.boaA.boaB was found to have a significant effect on the growth of the organism within murine macrophages (Fig 6B). At present, it is not clear whether BoaA and BoaB play a direct role in intracellular replication. It is possible that the absence of both Boa proteins in the OM of DD503.boaA.boaB affects the proper surface display of another molecule involved in this phenotypic trait. One candidate is LPS, as this molecule was previously shown to play an important role in the ability of B. pseudomallei to grow inside host cells $[93,94]$. B. pseudomallei produces multiple T3SS and T6SS that are involved in the intracellular lifestyle of the organism. These specialized secretion apparatuses are used to inject bacterial effector proteins inside host cells where they exert cytopathic effects or manipulate signaling pathways. One important step in this process is the proper docking of bacteria to the host cell to deliver the effectors. Given their roles in adherence, it is possible that the lack of expression of the boaA and boaB gene products interferes with the delivery of T3SS and/or T6SS cell-altering effectors, which in turn reduces the intracellular fitness of the double mutant strain DD503.boaA.boaB. The Yersinia pestis OM adhesin Ail was recently shown to affect delivery of Yop effector proteins to HEp2 cells and macrophages in such a manner [95]. Alternatively, the reduced intracellular growth of the double boa $A$ boaB mutant may be due to a greater sensitivity to immune effectors produced by the macrophages. The molecular basis for this phenotype is currently being investigated.

\section{Conclusion}

The present study reports the identification of B. pseudomallei and $B$. mallei gene products mediating adherence to epithelial cells. Because of their classification as select agents, there is currently a shortage of tools for genetic studies in B. pseudomallei and B. mallei (i.e. paucity of acceptable antibiotic markers, lack of low copy plasmids suitable for expressing surface proteins), which precluded us from complementing mutants. Our ability to express BoaA and BoaB in E. coli, however, conclusively demonstrates that the proteins directly mediate binding to epithelial cells. These results, along with our analyses of the mutant strains, clearly establish that these molecules participate in adherence by B. pseudomallei and B. mallei. Adherence is an essential step in pathogenesis by most infectious agents because it is necessary for colonization and precedes invasion of host cells by intracellular pathogens. Thus, continued investigation of BoaA and BoaB will yield important information regarding the biology and virulence of these organisms.

\section{Methods}

\section{Strains, plasmids, tissue culture cell lines and growth conditions}

The strains and plasmids used in this study are described in Table 3. B. pseudomallei and B. mallei were routinely cultured at $37^{\circ} \mathrm{C}$ using Low Salt Luria Bertani (LSLB) agar (Teknova) supplemented with polymyxin B [PmB] (100 $\mu \mathrm{g} / \mathrm{ml}$ for B. pseudomallei; $7.5 \mu \mathrm{g} / \mathrm{ml}$ for B. mallei), zeocin $(100 \mu \mathrm{g} / \mathrm{ml}$ for B. pseudomallei; $7.5 \mu \mathrm{g} / \mathrm{ml}$ for $B$. mallei), kanamycin [Kan] $(50 \mu \mathrm{g} / \mathrm{ml}$ for $B$. 
Table 3 Strains and plasmids

\begin{tabular}{|c|c|c|}
\hline Strain & Description & Reference \\
\hline \multicolumn{3}{|l|}{ B. pseudomallei } \\
\hline DD503 & Parental strain; polymyxin $B^{R}$ zeocin ${ }^{S}$ kanamycin ${ }^{S}$ streptomycin $^{R}$ & [107] \\
\hline DD503.boaA & Isogenic boaA mutant strain of DD503; polymyxin $B^{R} z^{2 e o c i n}{ }^{R}$ kanamycin $^{S}$ streptomycin $^{R}$ & This study \\
\hline DD503.boaB & Isogenic boaB mutant strain of DD503; polymyxin $B^{R} z^{2 e o c i n}{ }^{R}$ kanamycin $^{S}$ streptomycin $^{R}$ & This study \\
\hline $\begin{array}{l}\text { DD503.boaA. } \\
\text { boaB }\end{array}$ & Isogenic boaA boaB double mutant strain of DD503; polymyxin $B^{R} z e o c i n^{R}$ kanamycin ${ }^{R}$ streptomycin $^{S}$ & This study \\
\hline \multicolumn{3}{|l|}{ B. mallei } \\
\hline ATCC23344 & Wild-type strain; polymyxin $B^{R}$ zeocin ${ }^{S}$ kanamycin ${ }^{S}$ & [26] \\
\hline ATCC23344.boaA & Isogenic boaA mutant strain of ATCC23344; polymyxin $B^{R}$ zeocin $^{R}$ kanamycin $^{S}$ & This study \\
\hline \multicolumn{3}{|l|}{ E. coli } \\
\hline EPI300 & Cloning strain & $\begin{array}{l}\text { EPICENTRE }^{\oplus} \\
\text { Biotechnologies }\end{array}$ \\
\hline S17 & Strain used for conjugational transfer of suicide plasmids from E. coli to B. pseudomallei or B. mallei & [108] \\
\hline \multicolumn{3}{|l|}{ Plasmids } \\
\hline $\mathrm{pCC} 1^{\mathrm{TM}}$ & Cloning vector; chloramphenicol resistant $\left(\mathrm{Cm}^{\mathrm{R}}\right)$ & $\begin{array}{l}\text { EPICENTRE }^{\oplus} \\
\text { Biotechnologies }\end{array}$ \\
\hline pKAS46 & Mobilizable suicide plasmid; kanamycin $^{R}$ and ampicillin ${ }^{R}$ & [109] \\
\hline pCC1.3 & pCC1-based plasmid control, does not confer adherence; $\mathrm{Cm}^{\mathrm{R}}$ & [102] \\
\hline pSLboaA & pCC1 containing the B. mallei ATCC23344 boaA gene; $\mathrm{Cm}^{\mathrm{R}}$ & This study \\
\hline pSLboaAZEO & $\begin{array}{l}\text { pSLboaA in which a zeocin }{ }^{R} \text { marker was introduced near the middle of the boaA gene; } \mathrm{Cm}^{R} \text { and } \\
\text { zeocin }^{R}\end{array}$ & This study \\
\hline pKASboaAZEO & pKAS46 containing the insert from pSLboaAZEO; zeocin ${ }^{R}$, ampicillin ${ }^{R}$ and kanamycin $^{R}$ & This study \\
\hline pSLboaB & pCC1 containing the B. pseudomallei DD503 boaB gene; $\mathrm{Cm}^{\mathrm{R}}$ & This study \\
\hline pSLboaBZEO & $\begin{array}{l}\text { pSLboaB in which a zeocin }{ }^{R} \text { marker was introduced near the middle of the boaB gene; } \mathrm{Cm}^{R} \text { and } \\
\text { zeocin }^{R}\end{array}$ & This study \\
\hline pKASboaBZEO & pKAS46 containing the insert from pSLboaBZEO; zeocin ${ }^{R}$, ampicillin ${ }^{R}$ and kanamycin $^{R}$ & This study \\
\hline pKASboaB5' & $\begin{array}{l}\text { pKAS46 containing a 0.8-kb insert which corresponds to a region located within the } 5^{\prime} \text { end of the } B \text {. } \\
\text { pseudomallei DD503 boaB ORF; ampicillin }{ }^{R} \text { and kanamycin }{ }^{R}\end{array}$ & This study \\
\hline pKASboaB5'Amps ${ }^{\mathrm{s}}$ & pKASboaB5' in which the ampicillin ${ }^{R}$ marker was removed; ampicillin ${ }^{S}$ and kanamycin $^{R}$ & This study \\
\hline pEM7ZEO & Source of the zeocin ${ }^{R}$ marker; ampicillin ${ }^{R}$ and zeocin ${ }^{R}$ & Invitrogen ${ }^{\mathrm{TM}}$ \\
\hline
\end{tabular}

pseudomallei; $5 \mu \mathrm{g} / \mathrm{ml}$ for B. mallei), streptomycin [Sm] (used only for B. pseudomallei, $1000 \mu \mathrm{g} / \mathrm{ml}$ ) and glycerol (used only for $B$. mallei, $5 \%$ ), where indicated. Plategrown bacteria (20-hr growth for B. pseudomallei; 40-hr growth for B. mallei) were used for extraction of Sarkosyl-insoluble outer membrane proteins, preparation of whole cell lysates, RNA isolation, as well as for adherence, invasion, bactericidal, biofilm, and macrophage assays.

E. coli was cultured using LSLB containing $15 \mu \mathrm{g} / \mathrm{ml}$ chloramphenicol, $50 \mu \mathrm{g} / \mathrm{ml}$ Kan or $50 \mu \mathrm{g} / \mathrm{ml}$ zeocin, where indicated. For preparation of plasmid DNA, extraction of Sarkosyl-insoluble outer membrane proteins, RNA isolation, immunofluorescence labeling, as well as for adherence, invasion and macrophage assays, recombinant $E$. coli strains were grown in LSLB supplemented with the EPICENTRE ${ }^{\bullet}$ Biotechnologies CopyControl $^{\text {tw }}$ Induction Solution as previously reported [96].

The epithelial cell lines HEp2 (human laryngeal epithelium; ATCC CCL-23) and A549 (type II alveolar lung epithelium; ATCC CCL85) were cultured as outlined by others [97] and the murine macrophage cell line J774A.1 (ATCC TIB-67) was grown in DMEM medium (Mediatech, Inc) supplemented with $10 \%$ fetal bovine serum (Invitrogen ${ }^{\text {tut }}$ ) at $37^{\circ} \mathrm{C}$ and in the presence of $7.5 \% \mathrm{CO}_{2}$. Normal human bronchial epithelium (LONZA) were expanded, cryopreserved and cultured in an air-liquid interface system as previously described [67-69]. Normal human bronchial epithelium (NHBE) were grown on Transwell permeable inserts (Corning) and their apical surfaces were exposed to air for a minimum of 3 weeks prior to use in biological assays to ensure proper cellular differentiation and the development of functional cilia.

\section{Recombinant DNA methodology}

Standard molecular biology techniques were performed as described elsewhere [98]. Genomic DNA was isolated using the Invitrogen ${ }^{\mathrm{m}}$ Easy-DNA $^{\mathrm{mm}}$ kit. Plasmid DNA was obtained with the QIAprep Spin Miniprep Kit (Qiagen). The Failsafe ${ }^{\text {mix }}$ PCR System (EPICENTRE ${ }^{\bullet}$ Biotechnologies) was used to amplify the 5.5-kb boaA gene of $B$. 
mallei ATCC23344 with primers P1 (5'-TCA GAT GAA CCG CGT TTC CGT ATC-3') and P2 (5'-ACT CAT ACG GCT CGC GCA TAA A-3'). This amplicon was cloned in the vector $\mathrm{pCC}^{\mathrm{TM}}$ using the CopyControl ${ }^{\mathrm{m}}$ PCR Cloning Kit (EPICENTRE Biotechnologies), yielding the plasmid pSLboaA (Table 3). The 5.4-kb boaA gene of $B$. pseudomallei DD503 was amplified with P3 (5'-GCT TGC CGC ACG CAA TGG CT-3') and P4 (5'ATG GCG AGC GCG AAA CAT GGA AA-3') and the purified PCR product was used as a template in sequencing reactions. The 5.9-kb boaB gene of $B$. pseudomallei DD503 was generated with the Failsafe ${ }^{\mathrm{Ts}}$ PCR system using P5 (5'-TCC ATA AAT TCC CGG CGC TTG TTG-3') and P6 (5'-TGT CTC GAC ATC AGC GGT TCA CTT-3'), sequenced, and then cloned in $\mathrm{pCC}^{\mathrm{TM}}$ as described above, yielding the plasmid pSLboaB (Table 3). Of note, the inserts of plasmids pSLboaA and pSLboaB were sequenced to verify that PCR did not introduce mutations resulting in amino acid (aa) substitutions in the boaA and boaB gene products.

\section{Construction of boaA isogenic mutant strains of $B$. mallei and $B$. pseudomallei}

A $0.45-\mathrm{kb}$ zeocin ${ }^{\mathrm{R}}$ cassette was introduced into a unique NheI site located near the middle of the boaA ORF in pSLboaA. The resulting construct, designated pSLboaAZEO, was digested with $B a m H I$ and a 6-kb fragment corresponding to the boaA ORF interrupted by the zeo$\operatorname{cin}^{\mathrm{R}}$ marker was excised from an agarose gel, purified with the High Pure PCR Product Purification Kit (Roche Applied Science), and treated with the EPICENTRE ${ }^{\oplus}$ Biotechnologies End-It ${ }^{\mathrm{Tm}}$ DNA End Repair Kit. This blunt DNA fragment was then subcloned into the EcoR $V$ site of the suicide vector pKAS46. The resulting plasmid, pKASboaAZEO, was introduced into the E. coli strain $\mathrm{S} 17$ by electroporation and subsequently transferred into B. mallei ATCC23344 or B. pseudomallei DD503 by conjugation as reported by others [99].

Upon conjugation, B. pseudomallei colonies were first selected for resistance to $\mathrm{PmB}$ (to prevent growth of E. coli $\mathrm{S} 17$ ) and zeocin (to select strains containing the disrupted copy of boaA in their genome). These putative mutants were then tested for their sensitivity to kanamycin and resistance to streptomycin, which identified strains that did not contain the suicide vector pKAS46 integrated in their genome. Lastly, these $\mathrm{PmB}^{\mathrm{R}}$ zeocin ${ }^{\mathrm{R}}$ $\mathrm{Kan}^{\mathrm{S}} \mathrm{Sm}^{\mathrm{R}}$ conjugants were screened by PCR using Platinum $^{\odot} P f x$ DNA Polymerase (Invitrogen ${ }^{\mathrm{TM}}$ ) with the primers P7 (5'-TTG AGC ACG ACC AAC AGC AAC GTC-3') and P8 (5'-CCA ATG CGG TCG AAT GAT TGC C-3'), which led to the identification of the mutant strain DD503.boaA. These primers yielded a PCR product of $1.3-\mathrm{kb}$ in B. pseudomallei DD503 and a larger amplicon of $1.8-\mathrm{kb}$ in the mutant. The primers P9
(5'-TAT CGC AAG GTT TGG AAC AAG GCG-3') and P10 (5'-ACG CCG AAT ACC CTT GAT AGC TG-3') were also used to further confirm gene replacement in the B. pseudomallei mutant strain. These primers amplified DNA fragments of 5-kb in the parent strain DD503 and of $5.5-\mathrm{kb}$ in the isogenic boaA mutant. After the conjugative transfer of plasmid pKASboaAZEO into the B. mallei strain ATCC23344, colonies shown to be $\mathrm{PmB}^{\mathrm{R}}$, zeocin ${ }^{\mathrm{R}}$ and $\mathrm{Kan}^{\mathrm{S}}$ were screened by PCR with P7 and P8 as described above to identify the mutant strain ATCC23344.boaA. Of note, the boaA genes of both isogenic mutant strains DD503.boaA and ATCC23344. boaA were amplified and sequenced in their entirety to verify proper allelic exchange and successful disruption of boaA.

\section{Construction of a boaB B. pseudomallei isogenic mutant strain}

The plasmid pSLboaB was digested with NheI to remove a 162-bp fragment internal to the boaB ORF, treated with the End-It ${ }^{\mathrm{TM}}$ DNA End Repair Kit and ligated with the $0.45-\mathrm{kb}$ zeocin ${ }^{\mathrm{R}}$ marker to yield the construct pSLboaBZEO. This plasmid was digested with $\mathrm{BamHI}$ and a 6.2-kb fragment, which corresponds to the boaB ORF disrupted with the zeocin ${ }^{\mathrm{R}}$ cassette, was purified from agarose gel slices, subcloned into the suicide plasmid pKAS46 and introduced into B. pseudomallei DD503 by conjugation as described above. Conjugants shown to be $\mathrm{PmB}^{\mathrm{R}}$ zeocin ${ }^{\mathrm{R}} \mathrm{Kan}^{\mathrm{S}} \mathrm{Sm}^{\mathrm{R}}$ were screened by PCR using Platinum ${ }^{\circledR} P f x$ DNA Polymerase (Invitrogen ${ }^{\mathrm{Tn}}$ ) with primers P11 (5'-AGG TGG CGAC TCA AAT AGA ACC GT-3') and P12 (5'-GTT CGT GTT GTT GGC TAC GGC AAT-3') to identify the mutant strain DD503.boaB. These primers amplified a PCR product of $1.7-\mathrm{kb}$ in B. pseudomallei DD503 and of $2.0-\mathrm{kb}$ in the mutant. The primers P13 (5'-AGG TGG CGA CTC AAA TAG AAC CGT-3') and P10 were also used to further confirm gene replacement in the B. pseudomallei mutant strain. These primers generated amplicons of 5.2-kb and 5.5-kb in strains DD503 and DD503.boaB, respectively. Additionally, the boaB gene of DD503.boaB was amplified and both strands of the PCR product were sequenced to verify allelic exchange.

\section{Construction of a $B$. pseudomallei boaA boaB double mutant strain}

A 0.8 -kb PCR product, which corresponds to a region located within the 5'end of the B. pseudomallei DD503 boaB ORF, was amplified with Platinum ${ }^{\ominus} P f x$ DNA Polymerase (Invitrogen ${ }^{\mathrm{TM}}$ ) using primers P14 (5'-CTC GGG CTC AAT AAC ATG GC-3') and P15 (5'-CGG AAT TCC GGT TCG TGT TGT TGG CT-3'; EcoRI site underlined). This amplicon was digested with EcoR1 and directionally cloned into the EcoR $V$ and EcoR 1 sites of the 
suicide vector pKAS46, yielding the plasmid pKASboaB5, This construct was digested with ApaLI to remove a 0.8$\mathrm{kb}$ fragment corresponding to the ampicillin-resistance marker of pKAS46 and the resulting plasmid, pKASboa$\mathrm{B}^{\prime} \mathrm{Amp}^{\mathrm{S}}$, was introduced into the B. pseudomallei mutant strain DD503.boaA by conjugation as described above. Conjugants shown to be $\mathrm{PmB}^{\mathrm{R}}$ zeocin $^{\mathrm{R}} \operatorname{Kan}^{\mathrm{R}} \mathrm{Sm}^{\mathrm{S}}$ were screened by PCR using the MasterAmp ${ }^{\text {tw }}$ Extra-Long PCR kit (EPICENTRE ${ }^{\circ}$ Biotechnologies) with primers P13 and P10 to identify the mutant strain DD503.boaA.boaB. These primers amplified PCR products of $5.2-\mathrm{kb}$ in $B$. pseudomallei DD503 as well as in the single mutant DD503.boaA, and of $11.0-\mathrm{kb}$ in the double mutant strain DD503.boaA.boaB. These results indicated that the boaB gene in DD503.boaA.boaB had been disrupted by integration of the entire pKASboaB5'Amp ${ }^{\mathrm{S}}$ plasmid into the genome of B. pseudomallei.

\section{Quantitative reverse-transcriptase PCR (qRT-PCR)}

Total RNA was extracted from $10^{8}$ bacteria with the RNeasy Kit (Qiagen). One $\mu \mathrm{g}$ of total RNA was treated with RQ1 RNAse-Free DNase (Promega) and reverse transcribed with Improm II $^{\mathrm{mt}}$ Reverse transcriptase (Promega) using random hexamers (Invitrogen ${ }^{\mathrm{Tx}}$ ) under the manufacturer's recommended conditions. PCR quantification of specific cDNA levels was performed using a LightCycler ${ }^{\circ}$ (Roche Applied Science) rapid fluorescence temperature cycler as reported elsewhere [100]. Briefly, amplification was performed in a $10 \mu$ final volume containing $50 \mathrm{mM}$ Tris ( $\mathrm{pH} 8.3$ ), $3 \mathrm{mM} \mathrm{MgCl}, 4.5 \mu \mathrm{g}$ of bovine serum albumin, $200 \mu \mathrm{M}$ deoxynucleotide triphosphates, a 1:10,000 dilution of SYBR ${ }^{\circ}$ Green I (Molecular Probes, Inc.), $1 \mu \mathrm{M}$ each primer, and 1 unit of Platinum $^{\circ}$ Taq DNA Polymerase (Invitrogen ${ }^{\mathrm{Tw}}$ ). Amplification was performed for 40 cycles, with each run consisting of an initial melting at $95^{\circ} \mathrm{C}$ for 2 minutes, followed by melting, annealing, extension, and acquiring temperatures specific to each primer set. Serial dilutions of a representative template cDNA were amplified using each primer set to create a standard curve. Particular transcript levels in experimental samples were calculated by comparison to the corresponding standard curve. All calculated values for the boaA and boaB genes are normalized to either the Burkholderia recA or E. coli recA levels. A primer set for Borrelia burgdorferi recA [100] was used as a non-Burkholderia control to further demonstrate primer specificity (control in Fig 4). Negative controls in which the reverse transcriptase enzyme was not added to reaction mixtures were included in all experiments (data not shown). The boa and $r e c A$ transcripts were amplified from the same sets of samples. The primer sets used were: boaAF (5'-ATC GCG AAC AAT GCG AAC GAT GTC-3') and boaAR (5'-AAG CGA ATA AGC CTG ACC TGC GAT-3'), boaBF
(5'-AAT GCC GTA GCC AAC AAC ACG AAC-3') and boaBR (5'-TCG TCG AGT AAA GTT GCG AAC CGT3'), recABURKF (5'-CAC GAA CTG CCT CGT GAT CTT CAT-3') and recABURKR (5'-AAA TGC CTT CGC CGT ACA GGA TGT-3'), recACOLIF (5'-ATG GCT ATC GAC GAA AAC-3') and recACOLIR (5'GGT TTT ACC GGA AGA TTC C-3'), and recABbF (5'-GTC GAT CTA TTG TAT TAG ATG AGG CTC TCG-3') and recABbR (5'-GCC AAA GTT CTG CAA CAT TAA CAC CTA AAG-3').

\section{Nucleotide sequence analyses}

PCR products and plasmids were sequenced at the University of Michigan Sequencing Core. Chromatograms were assembled using the Sequencher 4.9 software (Gene Codes Corporation). The nucleotide sequences of the B. pseudomallei DD503 boaA (EF423807) and boaB (EF423808) genes were deposited in GenBank under the indicated accession number.

\section{Bioinformatic Analyses}

Sequence analyses were performed using Vector NTI (Invitrogen) and the various online tools available through the ExPASy Proteomics Server (http://au. expasy.org/). Signal sequence cleavage sites were determined using the SignalP 3.0 server (http://www.cbs.dtu. $\mathrm{dk} /$ services/SignalP/). The B. mallei ATCC23344 boaA gene product (locus tag BMAA0649) was identified by searching the genome of the organism for the presence of a YadA-like C-terminal domain (Pfam database number PF03895) through the NCBI genomic BLAST service using the tblastn and blastp programs (http://www.ncbi. nlm.nih.gov/sutils/genom_table.cgi). The other boaA and boa $B$ gene products described in this study were identified by using the predicted aa sequence of the B. mallei ATCC23344 BoaA protein to search the genomes of the B. mallei as well as B. pseudomallei strains available through the NCBI genomic BLAST service utilizing the tblastn and blastp programs. Structural features of the Boa proteins (e.g. helical regions, $\beta$-strands) were identified using the PSIPRED Protein Structure Prediction Server (http://bioinf.cs.ucl.ac.uk/psipred/).

\section{Epithelial cell adherence assays}

Quantitative attachment assays were performed as previously described by our laboratory [61,67]. Monolayers of A549 and HEp2 cells and cultures of NHBE were infected with $B$. mallei, B. pseudomallei or recombinant $E$. coli strains at a MOI of 100. Duplicate assays were repeated on at least 3 occasions for each strain, and adherence is expressed as the percentage ( \pm standard error) of bacteria attached to epithelial cells relative to the inoculum. Statistical analyses were performed using the Mann-Whitney test (GraphPad Prism 
software) and $P$ values $<0.05$ are reported as statistically significant.

\section{Biofilm and bactericidal assays}

These experiments were performed as previously described $[96,101,102]$. We used $50 \%$ and $25 \%$ normal human serum in bactericidal assays with $B$. pseudomallei and B. mallei, respectively.

\section{Macrophage survival assays}

Plate-grown bacteria were suspended in 5-ml of sterile PBS supplemented with $0.15 \%$ gelatin (PBSG) to a density of $10^{9} \mathrm{CFU} / \mathrm{ml}$. These suspensions were used to infect two identical sets of duplicate monolayers of J774A.1 cells $\left(10^{5}\right.$ cells/well; 24 -well tissue culture plate) at an MOI of 10 . The inoculated tissue culture plates were centrifuged (5-min, $165 \times g$ ) and incubated for 1hr at $37^{\circ} \mathrm{C}$, time after which the medium covering the monolayers was replaced with fresh tissue culture medium containing $50 \mu \mathrm{g} / \mathrm{ml}$ gentamicin. After a 2-hr incubation (i.e. 3-hr post infection), the wells of one tissue culture plate were washed, J774A.1 cells were lysed with a solution containing Saponin, and serial dilutions of the well contents were spread onto agar plates to determine the number of bacteria phagocytosed by the macrophages. The wells of the other tissue culture plate were washed once, fresh medium without antibiotics was added, and the plate was incubated for an additional 5-hr. Following this incubation (i.e. 8-hr post-infection), the wells were processed as described above in order to enumerate bacteria. These experiments were repeated on at least 3 separate occasions. Statistical analyses were performed using the Mann-Whitney test (GraphPad Prism software) and $P$ values $<0.05$ are reported as statistically significant.

\section{Epithelial cell invasion and survival assays}

These experiments were performed as described above for macrophage survival assays with some modifications. Specifically, epithelial cells were infected with an MOI of 100 . The inoculated tissue culture plates were centrifuged and incubated for $3-\mathrm{hr}$ at $37^{\circ} \mathrm{C}$, time after which the medium covering the monolayers was replaced with fresh tissue culture medium containing $50 \mu \mathrm{g} / \mathrm{ml}$ gentamicin. After a 2-hr incubation (i.e. 5-hr post infection), the wells of one tissue culture plate were washed and processed to enumerate intracellular bacteria as described above. The wells of the other tissue culture plate were washed once, fresh medium without antibiotics was added to wells, and the plate was incubated for an additional 3-hr. Following this incubation (i.e. 8-hr post-infection), the wells were processed as described above. These experiments were repeated on at least 3 separate occasions. Statistical analyses were performed using the Mann-Whitney test (GraphPad Prism software) and $P$ values $<0.05$ are reported as statistically significant

\section{Protein preparations, western blot, and antibody production}

Sarkosyl-insoluble OM proteins were obtained as previously described by Carlone et al [103]. The methods used to prepare whole cell lysates and perform western blot experiments are described elsewhere [61,62,67,104,105]. To obtain antibodies directed against BoaA, the peptide PEPA (NYLGGLFGFGPQTSMANWGDSSN) was synthesized and conjugated to maleimide-activated keyhole limpet hemocyanin (mcKLH, Thermo Scientific) under the manufacturer's recommended conditions. The sequence of PEPA corresponds to residues 78-100 of B. pseudomallei DD503 BoaA and encompasses aa 79-101 of B. mallei ATCC23344 BoaA (underlined residues in the PEPA sequence being perfectly conserved). The mcKLH-PEPA conjugate was emulsified in Freund's adjuvants and used to immunize female $B A L B / c$ mice as previously reported [106]. BoaB-specific antibodies were obtained by immunizing mice with mcKLH conjugated to the synthetic peptide PEPB (GWLLGTTSQTTDPGPLYPGPGAENN), which specifies aa 131-155 of B. pseudomallei DD503 BoaB. These animal studies were performed in compliance with institutional, as well as governmental, rules and regulations.

\section{Immunofluorescence labeling of $E$. coli and microscopy}

Plate-grown bacteria were suspended in $5-\mathrm{ml}$ of sterile PBSG to a density of $10^{8} \mathrm{CFU} / \mathrm{ml}$. Portions of these suspensions were spotted onto glass slides and dried using a warming plate. The slides were fixed with PBSG supplemented with $4 \%$ paraformaldehyde for 30-min at room temperature, washed with PBS supplemented with 0.05\% Tween 20 (PBST), and blocked overnight at $4^{\circ} \mathrm{C}$ using PBST supplemented with $10 \%$ goat serum $\left(\mathrm{SIGMA} \mathrm{ALDRICH}{ }^{\oplus}\right)$. Next, bacteria were probed for 1$\mathrm{hr}$ at room temperature with murine $\alpha$-BoaA or $\alpha$-BoaB antibodies diluted $(1: 200)$ in PBST supplemented with $10 \%$ goat serum. After this incubation, the slides were washed with PBST to remove unbound antibodies and incubated for 30-min at room temperature with a goat $\alpha$-mouse antibody labeled with Alexa Fluor 546 (Molecular Probes, Inc) and diluted (1:400) in PBST supplemented with $10 \%$ goat serum. Following this incubation, the slides were washed with PBST to remove unbound antibody and bacterial cells were stained using the nucleic acid dye DAPI (Molecular Probes, Inc). Slides were mounted with SlowFade ${ }^{\oplus}$ reagent $\left(\right.$ Invitrogen $^{\mathrm{Tm}}$ ) and examined by microscopy using a Zeiss LSM 510 Meta confocal system. 


\section{Abbreviations}

OM: outer membrane; aa: amino acid; ORF: open reading frame; Oca: oligomeric coiled-coil adhesin; MW: molecular weight; CFU: colony forming units; PmB: polymyxin B; Kan: kanamycin; Sm: streptomycin; nt: nucleotide; qRT-PCR: quantitative reverse-transcriptase PCR; CDNA: complementary DNA.

\section{Acknowledgements}

This study was supported by a grant from NIH/NIAID (Al062775) and startup funds from the University of Georgia College of Veterinary Medicine to ERL. The authors would like to thank Lauren Snipes and Frank Michel at the University of Georgia for their technical assistance.

\section{Author details}

'Department of Infectious Diseases, University of Georgia College of Veterinary Medicine, Athens, GA 30602, USA. ${ }^{2}$ Department of Medical Microbiology and Immunology, University of Toledo Health Sciences Campus, 3055 Arlington Avenue, Toledo, OH 43614, USA. ${ }^{3}$ Department of Microbiology and Infectious Diseases, University of Calgary Health Sciences Centre, 3330 Hospital Drive, NW Calgary, Alberta T2N 4N1, Canada.

\section{Authors' contributions}

RB helped conceive the study, participated in its design and coordination, performed most of the experiments involving live B. pseudomallei and $B$. mallei, and helped with redaction of the manuscript. SL performed several of the experiments involving live B. pseudomallei and B. mallei. JJL carried out the qRT-PCR experiments. WG carried out some of the macrophage survival assays with $B$. pseudomallei and helped with redaction of the manuscript. RMW contributed to the GRT-PCR experiments, participated in the conception and design of the study. RJH participated in generating antibodies against BoaA and BoaB. DEW provided the strains B. pseudomallei DD503, B. mallei ATCC23344, and E. coli S17, also participated in the design of the study. ERL conceived the study, participated in its design and coordination, performed experiments involving live B. pseudomallei and $B$. mallei, and helped with redaction of the manuscript. All authors read and approved the final manuscript.

Received: 7 August 2010 Accepted: 28 September 2010 Published: 28 September 2010

\section{References}

1. Cheng AC, Currie BJ: Melioidosis: epidemiology, pathophysiology, and management. Clin Microbiol Rev 2005, 18(2):383-416.

2. Wiersinga WJ, van der Poll T, White NJ, Day NP, Peacock SJ: Melioidosis: insights into the pathogenicity of Burkholderia pseudomallei. Nat Rev Microbiol 2006, 4(4):272-282.

3. Currie BJ, Fisher DA, Anstey NM, Jacups SP: Melioidosis: acute and chronic disease, relapse and re-activation. Trans R Soc Trop Med Hyg 2000, 94(3):301-304.

4. Currie BJ, Fisher DA, Howard DM, Burrow JN, Lo D, Selva-Nayagam S, Anstey NM, Huffam SE, Snelling PL, Marks PJ, Stephens DP, Lum GD, Jacups SP, Krause VL: Endemic melioidosis in tropical northern Australia: a 10-year prospective study and review of the literature. Clin Infect Dis 2000, 31(4):981-986.

5. Adler NR, Govan B, Cullinane M, Harper M, Adler B, Boyce JD: The molecular and cellular basis of pathogenesis in melioidosis: how does Burkholderia pseudomallei cause disease? FEMS Microbiol Rev 2009, 33(6):1079-1099

6. Wiersinga WJ, van der Poll T: Immunity to Burkholderia pseudomallei. Curr Opin Infect Dis 2009, 22(2):102-108.

7. Vietri NJ, Deshazer D: Melioidosis. Medical Aspects of Biological Warfare U.S Army Medical Department Borden Insitute Textbooks of Biological Warfare 2007, 147-166.

8. Bondi SK, Goldberg JB: Strategies toward vaccines against Burkholderia mallei and Burkholderia pseudomallei. Expert Rev Vaccines 2008, 7(9):1357-1365.

9. Galyov EE, Brett PJ, Deshazer D: Molecular Insights into Burkholderia pseudomallei and Burkholderia mallei Pathogenesis. Annu Rev Microbiol 2010, 64:495-517.
10. DeShazer D, Brett PJ, Woods DE: The type II O-antigenic polysaccharide moiety of Burkholderia pseudomallei lipopolysaccharide is required for serum resistance and virulence. Mol Microbiol 1998, 30(5):1081-1100.

11. Egan AM, Gordon DL: Burkholderia pseudomallei activates complement and is ingested but not killed by polymorphonuclear leukocytes. Infect Immun 1996, 64(12):4952-4959.

12. Reckseidler-Zenteno SL, DeVinney R, Woods DE: The capsular polysaccharide of Burkholderia pseudomallei contributes to survival in serum by reducing complement factor C3b deposition. Infect Immun 2005, 73(2):1106-1115.

13. Jones AL, DeShazer D, Woods DE: Identification and characterization of a two-component regulatory system involved in invasion of eukaryotic cells and heavy-metal resistance in Burkholderia pseudomallei. Infect Immun 1997, 65(12):4972-4977.

14. Jones AL, Beveridge TJ, Woods DE: Intracellular survival of Burkholderia pseudomallei. Infect Immun 1996, 64(3):782-790.

15. Burtnick MN, Woods DE: Isolation of polymyxin B-susceptible mutants of Burkholderia pseudomallei and molecular characterization of genetic loci involved in polymyxin B resistance. Antimicrob Agents Chemother 1999, 43(11):2648-2656.

16. Stevens JM, Ulrich RL, Taylor LA, Wood MW, Deshazer D, Stevens MP, Galyov EE: Actin-binding proteins from Burkholderia mallei and Burkholderia thailandensis can functionally compensate for the actinbased motility defect of a Burkholderia pseudomallei bimA mutant. J Bacteriol 2005, 187(22):7857-7862.

17. Stevens MP, Stevens JM, Jeng RL, Taylor LA, Wood MW, Hawes P, Monaghan P, Welch MD, Galyov EE: Identification of a bacterial factor required for actin-based motility of Burkholderia pseudomallei. Mol Microbiol 2005, 56(1):40-53.

18. Stevens MP, Galyov EE: Exploitation of host cells by Burkholderia pseudomallei. Int J Med Microbiol 2004, 293(7-8):549-555.

19. Holden MT, Titball RW, Peacock SJ, Cerdeno-Tarraga AM, Atkins T, Crossman LC, Pitt T, Churcher C, Mungall K, Bentley SD, Sebaihia M, Thomson NR, Bason N, Beacham IR, Brooks K, Brown KA, Brown NF, Challis GL, Cherevach I, Chillingworth T, Cronin A, Crossett B, Davis P, DeShazer D, Feltwell T, Fraser A, Hance Z, Hauser H, Holroyd S, Jagels $\mathrm{K}$, Keith KE, Maddison M, Moule S, Price C, Quail MA, Rabbinowitsch E, Rutherford K, Sanders M, Simmonds M, Songsivilai S, Stevens K, Tumapa S, Vesaratchavest M, Whitehead S, Yeats C, Barrell BG, Oyston PC, Parkhill J: Genomic plasticity of the causative agent of melioidosis, Burkholderia pseudomallei. Proc Natl Acad Sci USA 2004, 101(39):14240-14245.

20. Arun S, Neubauer H, Gurel A, Ayyildiz G, Kuscu B, Yesildere T, Meyer H, Hermanns W: Equine glanders in Turkey. Vet Rec 1999, 144(10):255-258

21. Neubauer $\mathrm{H}$, Meyer $\mathrm{H}$, Finke EJ: Human glanders. Revue Internationale des Senvices de Sante des Forces Armees 1997, 70:258-265.

22. Whitlock GC, Estes DM, Torres AG: Glanders: off to the races with Burkholderia mallei. FEMS Microbiol Lett 2007, 277(2):115-122.

23. Srinivasan A, Kraus CN, DeShazer D, Becker PM, Dick JD, Spacek L, Bartlett JG, Byrne WR, Thomas DL: Glanders in a military research microbiologist. N Engl J Med 2001, 345(4):256-258.

24. Gregory BC, Waag DM: Glanders. Medical Aspects of Biological Warfare U.S Army Medical Department Borden Insitute Textbooks of Biological Warfare 2007, 121-146.

25. Waag DM, Deshazer D: Glanders: New insights into an old disease. In Biological Weapons Defense: Infectious Diseases and Counterbioterrorism. Edited by: Lindler LE LF, Korch GW. Totowa, New Jersey: Humana Press Inc; 2004.

26. Nierman WC, DeShazer D, Kim HS, Tettelin H, Nelson KE, Feldblyum T, Ulrich RL, Ronning CM, Brinkac LM, Daugherty SC, Davidsen TD, Deboy RT, Dimitrov G, Dodson RJ, Durkin AS, Gwinn ML, Haft DH, Khouri $H$, Kolonay JF, Madupu R, Mohammoud Y, Nelson WC, Radune D, Romero CM, Sarria S, Selengut J, Shamblin C, Sullivan SA, White O, Yu Y, Zafar N, Zhou L, Fraser CM: Structural flexibility in the Burkholderia mallei genome. Proc Natl Acad Sci USA 2004, 101(39):14246-14251.

27. Kumar A, Chua KL, Schweizer HP: Method for regulated expression of single-copy efflux pump genes in a surrogate Pseudomonas aeruginosa strain: identification of the BpeEF-OprC chloramphenicol and trimethoprim efflux pump of Burkholderia pseudomallei 1026b. Antimicrob Agents Chemother 2006, 50(10):3460-3463. 
28. Harland DN, Dassa E, Titball RW, Brown KA, Atkins HS: ATP-binding cassette systems in Burkholderia pseudomallei and Burkholderia mallei. BMC Genomics 2007, 8:83.

29. Tribuddharat C, Moore RA, Baker P, Woods DE: Burkholderia pseudomallei class a beta-lactamase mutations that confer selective resistance against ceftazidime or clavulanic acid inhibition. Antimicrob Agents Chemother 2003, 47(7):2082-2087.

30. Dance DA, Wuthiekanun V, Chaowagul W, White NJ: The antimicrobial susceptibility of Pseudomonas pseudomallei. Emergence of resistance in vitro and during treatment. J Antimicrob Chemother 1989, 24(3):295-309.

31. Jenney AW, Lum G, Fisher DA, Currie BJ: Antibiotic susceptibility of Burkholderia pseudomallei from tropical northern Australia and implications for therapy of melioidosis. Int J Antimicrob Agents 2001, 17(2):109-113.

32. Thibault FM, Hernandez E, Vidal DR, Girardet M, Cavallo JD: Antibiotic susceptibility of 65 isolates of Burkholderia pseudomallei and Burkholderia mallei to 35 antimicrobial agents. J Antimicrob Chemother 2004, 54(6):1134-1138.

33. Wuthiekanun V, Cheng AC, Chierakul W, Amornchai P, Limmathurotsakul D, Chaowagul W, Simpson AJ, Short JM, Wongsuvan G, Maharjan B, White NJ, Peacock SJ: Trimethoprim/sulfamethoxazole resistance in clinical isolates of Burkholderia pseudomallei. J Antimicrob Chemother 2005, 55(6):1029-1031.

34. Ho PL, Cheung TK, Yam WC, Yuen KY: Characterization of a laboratorygenerated variant of BPS beta-lactamase from Burkholderia pseudomallei that hydrolyses ceftazidime. J Antimicrob Chemother 2002, 50(5):723-726.

35. Cheung TK, Ho PL, Woo PC, Yuen KY, Chau PY: Cloning and expression of class $A$ beta-lactamase gene blaA(BPS) in Burkholderia pseudomallei. Antimicrob Agents Chemother 2002, 46(4):1132-1135.

36. Niumsup P, Wuthiekanun V: Cloning of the class D beta-lactamase gene from Burkholderia pseudomallei and studies on its expression in ceftazidime-susceptible and -resistant strains. J Antimicrob Chemother 2002, 50(4):445-455.

37. Wuthiekanun V, Peacock SJ: Management of melioidosis. Expert Rev Anti Infect Ther 2006, 4(3):445-455.

38. Peacock SJ, Schweizer HP, Dance DA, Smith TL, Gee JE, Wuthiekanun V, Deshazer D, Steinmetz I, Tan P, Currie BJ: Management of accidental laboratory exposure to Burkholderia pseudomallei and B. mallei. Emerg Infect Dis 2008, 14(7):e2.

39. Cheng AC, McBryde ES, Wuthiekanun V, Chierakul W, Amornchai P, Day NP, White NJ, Peacock SJ: Dosing regimens of cotrimoxazole (trimethoprimsulfamethoxazole) for melioidosis. Antimicrob Agents Chemother 2009, 53(10):4193-4199.

40. Burtnick MN, Brett PJ, Woods DE: Molecular and physical characterization of Burkholderia mallei O antigens. J Bacteriol 2002, 184(3):849-852.

41. Ribot WJ, Ulrich RL: The animal pathogen-like type III secretion system is required for the intracellular survival of Burkholderia mallei within J774.2 macrophages. Infect Immun 2006, 74(7):4349-4353.

42. Kenny DJ, Russell P, Rogers D, Eley SM, Titball RW: In vitro susceptibilities of Burkholderia mallei in comparison to those of other pathogenic Burkholderia spp. Antimicrob Agents Chemother 1999, 43(11):2773-2775.

43. Schell MA, Ulrich RL, Ribot WJ, Brueggemann EE, Hines HB, Chen D, Lipscomb L, Kim HS, Mrazek J, Nierman WC, Deshazer D: Type VI secretion is a major virulence determinant in Burkholderia mallei. Mol Microbiol 2007, 64(6):1466-1485

44. Shalom G, Shaw JG, Thomas MS: In vivo expression technology identifies a type VI secretion system locus in Burkholderia pseudomallei that is induced upon invasion of macrophages. Microbiology 2007, 153(Pt 8):2689-2699.

45. Warawa J, Woods DE: Type III secretion system cluster 3 is required for maximal virulence of Burkholderia pseudomallei in a hamster infection model. FEMS Microbiol Lett 2005, 242(1):101-108.

46. Ulrich RL, DeShazer D: Type III secretion: a virulence factor delivery system essential for the pathogenicity of Burkholderia mallei. Infect Immun 2004, 72(2):1150-1154.

47. Stevens MP, Haque A, Atkins T, Hill J, Wood MW, Easton A, Nelson M, Underwood-Fowler C, Titball RW, Bancroft GJ, Galyov EE: Attenuated virulence and protective efficacy of a Burkholderia pseudomallei bsa type III secretion mutant in murine models of melioidosis. Microbiology 2004, 150(Pt 8):2669-2676.
48. Stevens MP, Wood MW, Taylor LA, Monaghan P, Hawes P, Jones PW, Wallis TS, Galyov EE: An Inv/Mxi-Spa-like type III protein secretion system in Burkholderia pseudomallei modulates intracellular behaviour of the pathogen. Mol Microbiol 2002, 46(3):649-659.

49. Burtnick MN, DeShazer D, Nair V, Gherardini FC, Brett PJ: Burkholderia mallei cluster 1 type VI secretion mutants exhibit growth and actin polymerization defects in RAW 264.7 murine macrophages. Infect Immun 78(1):88-99.

50. St Geme JW: Bacterial adhesins: determinants of microbial colonization and pathogenicity. Adv Pediatr 1997, 44:43-72

51. Boyle EC, Finlay BB: Bacterial pathogenesis: exploiting cellular adherence. Curr Opin Cell Biol 2003, 15(5):633-639.

52. Samrakandi MM, Ridenour DA, Yan L, Cirillo JD: Entry into host cells by Legionella. Front Biosci 2002, 7:d1-11.

53. Inglis TJ, Robertson T, Woods DE, Dutton N, Chang BJ: Flagellum-mediated adhesion by Burkholderia pseudomallei precedes invasion of Acanthamoeba astronyxis. Infect Immun 2003, 71(4):2280-2282.

54. Boddey JA, Flegg CP, Day CJ, Beacham IR, Peak IR: Temperature-regulated microcolony formation by Burkholderia pseudomallei requires pilA and enhances association with cultured human cells. Infect Immun 2006, 74(9):5374-5381

55. Hoiczyk E, Roggenkamp A, Reichenbecher M, Lupas A, Heesemann J: Structure and sequence analysis of Yersinia YadA and Moraxella UspAs reveal a novel class of adhesins. Embo J 2000, 19(22):5989-5999.

56. Roggenkamp A, Ackermann N, Jacobi CA, Truelzsch K, Hoffmann H, Heesemann J: Molecular analysis of transport and oligomerization of the Yersinia enterocolitica adhesin YadA. J Bacteriol 2003, 185(13):3735-3744.

57. Nummelin H, Merckel MC, Leo JC, Lankinen H, Skurnik M, Goldman A: The Yersinia adhesin YadA collagen-binding domain structure is a novel lefthanded parallel beta-roll. Embo J 2004, 23(4):701-711.

58. Yeo HJ, Cotter SE, Laarmann S, Juehne T, St Geme JW, Waksman G: Structural basis for host recognition by the Haemophilus influenzae Hia autotransporter. Embo J 2004, 23(6):1245-1256.

59. Laarmann S, Cutter D, Juehne T, Barenkamp SJ, St Geme JW: The Haemophilus influenzae Hia autotransporter harbours two adhesive pockets that reside in the passenger domain and recognize the same host cell receptor. Mol Microbiol 2002, 46(3):731-743.

60. Surana NK, Cutter D, Barenkamp SJ, St Geme JW: The Haemophilus influenzae Hia autotransporter contains an unusually short trimeric translocator domain. J Biol Chem 2004, 279(15):14679-14685.

61. Bullard B, Lipski SL, Lafontaine ER: Hag directly mediates the adherence of Moraxella catarrhalis to human middle ear cells. Infect Immun 2005, 73(8):5127-5136.

62. Bullard B, Lipski S, Lafontaine ER: Regions important for the adhesin activity of Moraxella catarrhalis Hag. BMC Microbiol 2007, 7:65.

63. Henderson IR, Navarro-Garcia F, Desvaux M, Fernandez RC, Ala'Aldeen D: Type $\mathrm{V}$ protein secretion pathway: the autotransporter story. Microbio/ Mol Biol Rev 2004, 68(4):692-744.

64. Linke D, Riess T, Autenrieth IB, Lupas A, Kempf VA: Trimeric autotransporter adhesins: variable structure, common function. Trends Microbiol 2006, 14(6):264-270.

65. Cotter SE, Surana NK, St Geme JW: Trimeric autotransporters: a distinct subfamily of autotransporter proteins. Trends Microbiol 2005, 13(5):199-205.

66. Balder R, Hassel J, Lipski S, Lafontaine ER: Moraxella catarrhalis strain O35E expresses two filamentous hemagglutinin-like proteins that mediate adherence to human epithelial cells. Infect Immun 2007, 75(6):2765-2775

67. Balder R, Krunkosky TM, Nguyen CQ, Feezel L, Lafontaine ER: Hag mediates adherence of Moraxella catarrhalis to ciliated human airway cells. Infect Immun 2009, 77(10):4597-4608.

68. Krunkosky TM, Fischer BM, Martin LD, Jones N, Akley NJ, Adler KB: Effects of TNF-alpha on expression of ICAM-1 in human airway epithelial cells in vitro. Signaling pathways controlling surface and gene expression. Am J Respir Cell Mol Biol 2000, 22(6):685-692.

69. Krunkosky TM, Jordan JL, Chambers E, Krause DC: Mycoplasma pneumoniae host-pathogen studies in an air-liquid culture of differentiated human airway epithelial cells. Microb Pathog 2007, 42(23):98-103.

70. Capecchi B, Adu-Bobie J, Di Marcello F, Ciucchi L, Masignani V, Taddei A, Rappuoli R, Pizza M, Arico B: Neisseria meningitidis NadA is a new invasin 
which promotes bacterial adhesion to and penetration into human epithelial cells. Mol Microbiol 2005, 55(3):687-698.

71. Valle J, Mabbett AN, Ulett GC, Toledo-Arana A, Wecker K, Totsika M, Schembri MA, Ghigo JM, Beloin C: UpaG, a new member of the trimeric autotransporter family of adhesins in uropathogenic Escherichia coli. J Bacteriol 2008, 190(12):4147-4167.

72. Fexby S, Bjarnsholt T, Jensen PO, Roos V, Hoiby N, Givskov M, Klemm P. Biological Trojan horse: Antigen 43 provides specific bacterial uptake and survival in human neutrophils. Infect Immun 2007, 75(1):30-34.

73. Attia AS, Lafontaine ER, Latimer JL, Aebi C, Syrogiannopoulos GA, Hansen EJ: The UspA2 protein of Moraxella catarrhalis is directly involved in the expression of serum resistance. Infect Immun 2005, 73(4):2400-2410.

74. Pearson MM, Hansen EJ: Identification of Gene Products Involved in Biofilm Production by Moraxella catarrhalis ETSU-9 In Vitro. Infect Immun 2007, 75(9):4316-4325.

75. Wang W, Pearson MM, Attia AS, Blick RJ, Hansen EJ: A UspA2H-negative variant of Moraxella catarrhalis strain O46E has a deletion in a homopolymeric nucleotide repeat common to uspA2H genes. Infect Immun 2007, 75(4):2035-2045

76. Farn JL, Strugnell RA, Hoyne PA, Michalski WP, Tennent JM: Molecular characterization of a secreted enzyme with phospholipase B activity from Moraxella bovis. J Bacteriol 2001, 183(22):6717-6720.

77. Timpe JM, Holm MM, Vanlerberg SL, Basrur V, Lafontaine ER: Identification of a Moraxella catarrhalis outer membrane protein exhibiting both adhesin and lipolytic activities. Infect Immun 2003, 71(8):4341-4350.

78. Maroncle NM, Sivick KE, Brady R, Stokes FE, Mobley HL: Protease activity, secretion, cell entry, cytotoxicity, and cellular targets of secreted autotransporter toxin of uropathogenic Escherichia coli. Infect Immun 2006, 74(11):6124-6134

79. Lafontaine ER, Cope LD, Aebi C, Latimer JL, McCracken GH Jr, Hansen EJ: The UspA1 protein and a second type of UspA2 protein mediate adherence of Moraxella catarrhalis to human epithelial cells in vitro. J Bacteriol 2000, 182(5):1364-1373.

80. Sherlock O, Schembri MA, Reisner A, Klemm P: Novel roles for the AIDA adhesin from diarrheagenic Escherichia coli: cell aggregation and biofilm formation. J Bacteriol 2004, 186(23):8058-8065.

81. Tiyawisutsri R, Holden MT, Tumapa S, Rengpipat S, Clarke SR, Foster SJ, Nierman WC, Day NP, Peacock SJ: Burkholderia Hep_Hap autotransporter (BuHA) proteins elicit a strong antibody response during experimental glanders but not human melioidosis. BMC Microbiol 2007, 7:19.

82. Schell MA, Lipscomb L, DeShazer D: Comparative genomics and an insect model rapidly identify novel virulence genes of Burkholderia mallei. Bacteriol 2008, 190(7):2306-2313.

83. Kespichayawattana W, Intachote $P$, Utaisincharoen P, Sirisinha S: Virulent Burkholderia pseudomallei is more efficient than avirulent Burkholderia thailandensis in invasion of and adherence to cultured human epithelial cells. Microb Pathog 2004, 36(5):287-292.

84. Deshazer D: Virulence of clinical and environmental isolates of Burkholderia oklahomensis and Burkholderia thailandensis in hamsters and mice. FEMS Microbiol Lett 2007, 277(1):64-69.

85. Brett PJ, Deshazer D, Woods DE: Characterization of Burkholderia pseudomallei and Burkholderia pseudomallei-like strains. Epidemiol Infect 1997, 118(2):137-148.

86. Smith MD, Angus BJ, Wuthiekanun V, White NJ: Arabinose assimilation defines a nonvirulent biotype of Burkholderia pseudomallei. Infect Immun 1997, 65(10):4319-4321.

87. Ulett GC, Currie BJ, Clair TW, Mayo M, Ketheesan N, Labrooy J, Gal D, Norton R, Smith CA, Barnes J, Warner J, Hirst RG: Burkholderia pseudomallei virulence: definition, stability and association with clonality. Microbes Infect 2001, 3(8):621-631.

88. DeShazer D, Waag DM, Fritz DL, Woods DE: Identification of a Burkholderia mallei polysaccharide gene cluster by subtractive hybridization and demonstration that the encoded capsule is an essential virulence determinant. Microb Pathog 2001, 30(5):253-269.

89. Kim HS, Schell MA, Yu Y, Ulrich RL, Sarria SH, Nierman WC, DeShazer D: Bacterial genome adaptation to niches: divergence of the potential virulence genes in three Burkholderia species of different survival strategies. BMC Genomics 2005, 6:174

90. Druar C, Yu F, Barnes JL, Okinaka RT, Chantratita N, Beg S, Stratilo CW, Olive AJ, Soltes G, Russell ML, Limmathurotsakul D, Norton RE, Ni SX,
Picking WD, Jackson PJ, Stewart DI, Tsvetnitsky V, Picking WL, Cherwonogrodzky JW, Ketheesan N, Peacock SJ, Wiersma EJ: Evaluating Burkholderia pseudomallei Bip proteins as vaccines and Bip antibodies as detection agents. FEMS Immunol Med Microbiol 2008, 52(1):78-87.

91. Chantratita N, Wuthiekanun V, Boonbumrung K, Tiyawisutsri R, Vesaratchavest M, Limmathurotsakul D, Chierakul W, Wongratanacheewin S, Pukritiyakamee S, White NJ, Day NP, Peacock SJ: Biological relevance of colony morphology and phenotypic switching by Burkholderia pseudomallei. J Bacteriol 2007, 189(3):807-817.

92. Felgner PL, Kayala MA, Vigil A, Burk C, Nakajima-Sasaki R, Pablo J, Molina DM, Hirst S, Chew JS, Wang D, Tan G, Duffield M, Yang R, Neel J, Chantratita N, Bancroft G, Lertmemongkolchai G, Davies DH, Baldi P, Peacock S, Titball RW: A Burkholderia pseudomallei protein microarray reveals serodiagnostic and cross-reactive antigens. Proc Natl Acad Sci USA 2009, 106(32):13499-13504.

93. Arjcharoen S, Wikraiphat C, Pudla M, Limposuwan K, Woods DE, Sirisinha S, Utaisincharoen P: Fate of a Burkholderia pseudomallei lipopolysaccharide mutant in the mouse macrophage cell line RAW 264.7: possible role for the O-antigenic polysaccharide moiety of lipopolysaccharide in internalization and intracellular survival. Infect Immun 2007, 75(9):4298-4304.

94. Tangsudjai S, Pudla M, Limposuwan K, Woods DE, Sirisinha S, Utaisincharoen P: Involvement of the MyD88-independent pathway in controlling the intracellular fate of Burkholderia pseudomallei infection in the mouse macrophage cell line RAW 264.7. Microbiol Immunol 54(5):282-290.

95. Felek S, Krukonis ES: The Yersinia pestis Ail protein mediates binding and Yop delivery to host cells required for plague virulence. Infect Immun 2009, 77(2):825-836.

96. Lipski SL, Holm MM, Lafontaine ER: Identification of a Moraxella catarrhalis gene that confers adherence to various human epithelial cell lines in vitro. FEMS Microbiol Lett 2007, 267(2):207-213.

97. Lipski SL, Akimana C, Timpe JM, Wooten RM, Lafontaine ER: The Moraxella catarrhalis Autotransporter McaP Is a Conserved Surface Protein That Mediates Adherence to Human Epithelial Cells through Its N-Terminal Passenger Domain. Infect Immun 2007, 75(1):314-324.

98. Sambrook J, Russell DW: Molecular Cloning: A Laboratory Manual (Third Edition). Cold Spring Harbor Laboratory Press, Third 2001.

99. Burtnick M, Bolton A, Brett P, Watanabe D, Woods D: Identification of the acid phosphatase (acpA) gene homologues in pathogenic and nonpathogenic Burkholderia spp. facilitates TnphoA mutagenesis. Microbiology 2001, 147(Pt 1):111-120.

100. Lazarus JJ, Meadows MJ, Lintner RE, Wooten RM: IL-10 deficiency promotes increased Borrelia burgdorferi clearance predominantly through enhanced innate immune responses. J Immunol 2006, 177(10):7076-7085

101. Aebi C, Lafontaine ER, Cope LD, Latimer JL, Lumbley SL, McCracken GH Jr, Hansen EJ: Phenotypic effect of isogenic uspA1 and uspA2 mutations on Moraxella catarrhalis 035E. Infect Immun 1998, 66(7):3113-3119.

102. Holm MM, Vanlerberg SL, Foley IM, Sledjeski DD, Lafontaine ER: The Moraxella catarrhalis porin-like outer membrane protein $C D$ is an adhesin for human lung cells. Infect Immun 2004, 72(4):1906-1913.

103. Carlone GM, Thomas ML, Rumschlag HS, Sottnek FO: Rapid microprocedure for isolating detergent-insoluble outer membrane proteins from Haemophilus species. J Clin Microbiol 1986, 24(3):330-332.

104. Cope LD, Lafontaine ER, Slaughter CA, Hasemann CA Jr, Aebi C, Henderson FW, McCracken GH Jr, Hansen EJ: Characterization of the Moraxella catarrhalis uspA1 and uspA2 genes and their encoded products. J Bacteriol 1999, 181(13):4026-4034.

105. Patrick CC, Kimura A, Jackson MA, Hermanstorfer L, Hood A, McCracken GH $\mathrm{Jr}$, Hansen EJ: Antigenic characterization of the oligosaccharide portion of the lipooligosaccharide of nontypable Haemophilus influenzae. Infect Immun 1987, 55(12):2902-2911.

106. Lafontaine ER, Wagner NJ, Hansen EJ: Expression of the Moraxella catarrhalis UspA1 protein undergoes phase variation and is regulated at the transcriptional level. J Bacteriol 2001, 183(5):1540-1551.

107. Moore RA, DeShazer D, Reckseidler S, Weissman A, Woods DE: Effluxmediated aminoglycoside and macrolide resistance in Burkholderia pseudomallei. Antimicrob Agents Chemother 1999, 43(3):465-470. 
108. Simon $R$, Priefer $U$, Puhler $A$ : A broad host range mobilisation system for in vivo genetic engineering: transposon mutagenesis in gram-negative bacteria. Bio/Technology 1983, 1:784-791.

109. Skorupski K, Taylor RK: Positive selection vectors for allelic exchange. Gene 1996, 169(1):47-52

doi:10.1186/1471-2180-10-250

Cite this article as: Balder et al:: Identification of Burkholderia mallei and

Burkholderia pseudomallei adhesins for human respiratory epithelial

cells. BMC Microbiology 2010 10:250

Submit your next manuscript to BioMed Central and take full advantage of:

- Convenient online submission

- Thorough peer review

- No space constraints or color figure charges

- Immediate publication on acceptance

- Inclusion in PubMed, CAS, Scopus and Google Scholar

- Research which is freely available for redistribution

Submit your manuscript at www.biomedcentral.com/submit
Ciomed Central 